\title{
PÓŹNOGOTYCKI OLTARZ ŚW. KATARZYNY SIENEŃSKIEJ Z KOŚCIOŁA OO. DOMINIKANÓW W KRAKOWIE
}

\author{
Identyfikacja zabytku
}

W ostatnio wydanej książce J. Gadomski pisze o mało znanym ołtarzu św. Katarzyny Sieneńskiej z krakowskiego kościoła OO. Dominikanów: „Kaplicę Św. Katarzyny ze Sieny (później Zbaraskich) zdobił zainstalowany tam na przełomie XV i XVI w. tryptyk ze scenami z życia tej świętej, dziś zaginiony"1. Następnie zaś: „W kaplicy Sw. Katarzyny ze Sieny przy krakowskim kościele dominikanów znajdował się ołtarz poświęcony tej mistyczce i stygmatyczce dominikańskiej XIV wieku. Na nie istniejącej już nastawie ołtarzowej powstałej na przełomie XV i XVI w. a znanej $\mathrm{z}$ akwarelowych kopii przedstawiono na skrzydłach cztery sceny z życia Św. Katarzyny, mianowicie: 1 . Wymianę serc między Św. Katarzyną a Chrystusem. 2. Chrystusa podającego hostię Sw. Katarzynie. 3. Katarzyna napastowana przez demony. 4. Sw. Katarzyna pijąca krew z rany Chrystusa" 2 .

Okazało się, że ołtarz ten istnieje do dziś, przechowywany w Muzeum Narodowym w Warszawie, po dokonaniu konserwacji w pracowni mgr Ewy Kołodziejskiej. Są to cztery kwatery (il. 1 - 8) obustronnie malowane, stanowiące niegdyś dwa skrzydła ołtarza (nr inw. 210200). Malowidła te, przemalowane w XVII i XIX w., nie budziły dotąd większego zainteresowania; były jedynie trzykrotnie tematem prac magisterskich studentów Wydziału Konserwatorstwa Akademii Sztuk Pięknych w Warszawie ${ }^{3}$. Prace te, aczkolwiek noszące jeszcze znamiona prac „ćwiczebnych”, wniosły kilka ustaleń

${ }^{1} \mathrm{~J}$. G a dom s ki, Gotyckie malarstwo tablicowe Matopolski, 1460 - 1500, Warszawa 1988, s. 37 (przypis 178).

2 Tamże, s. 62 (przypis 363, 364).

${ }^{3}$ T. S a dzi a k, Atrybucja kwatery ottarza Swiętej Katarzyny ze Sieny, Warszawa 1971 (maszynopis w posiadaniu Muzeum Narodowego w Warszawie); E. Nag a j, Wyobrażenia Swiętej Katarzyny ze Sieny na podstawie malarstwa włoskiego $i$ wybranych przykładów malarstwa polskiego od XIV do XVIII wieku, Warszawa 1978 (maszynopis tamże); E. Koł o dzi e j s k a, Kwatery ottarza Św. Katarzyny Sieneńskiej na tle malarstwa polskiego poczq̨tków XVI w., Warszawa 1986 (maszynopis tamże). 
ważnych dla problematyki ołtarza: przede wszystkim rozpoznanie ikonograficzne i próbną propozycję rekonstrukcji ołtarza ${ }^{4}$ oraz dostrzeżenie w zabytku związków z malarstwem małopolskim początku XVI w. ${ }^{5}$ Zasługą tych prac studenckich jest także zdjęcie przemalówek i odsłonięcie kwater ołtarza ${ }^{6}$. Trudnym problemem była dotąd kwestia pochodzenia zabytku. Brak dokładności w dotarciu do właściwego inwentarza sprawil, że przez wiele lat określano ołtarz jako dzieło, ogólnie mówiąc, pochodzące $\mathrm{z}$ województwa krakowskiego lub Małopolski, przywiezione do Warszawy w 1947 r. Magistranci lokowali je w Raciborzu (Sadziak) lub w Piotrkowie (Kołodziejska). Natomiast inwentarz z numerem wyżej cytowanym, udostępniony mi przez adiunkta działu średniowiecznego mgr Paulinę Ratowską, podaje wyraźnie, że ołtarz przywieziony został z Krakowa w transporcie rewindykatów. Trudno dziś ustalić, dlaczego ta informacja odnalazła się dopiero po wielu latach. Być może uważano, że ołtarz (w stanie przemalowanym) jest za słaby stylistycznie, aby mógł pochodzić $\mathrm{z}$ większego ośrodka sztuki i do Krakowa dostał się z innej miejscowości. Ten błąd, zakorzeniony w dotychczasowych opiniach o pochodzeniu ołtarza, zaważył i na moich początkowych badaniach. Skłonił mnie mianowicie do rozpisania szerokiej kwerendy, obejmującej całą Małopolskę (dawne województwa: krakowskie, kieleckie i katowickie) w celu odnalezienia kościołów o wezwaniu św. Katarzyny Sieneńskiej, w odróżnieniu od św. Katarzyny Aleksandryjskiej. Zasadą Katalogu zabytków i innych opracowań jest niepodawanie tej informacji. Kwerenda moja wykazała, że na 42 kościoły noszące wezwanie św. Katarzyny, jedynym sanktuarium pod wezwaniem św. Katarzyny Sieneńskiej jest kaplica Zbaraskich przy kościele Dominikanów w Krakowie. Inne kościoły małopolskie mają wezwanie św. Katarzyny Aleksandryjskiej. Ten wynik kwerendy skierował moją uwagę na obiekt krakowski. Drogą eliminacji bowiem mogłam ustalić hipotetyczne miejsce pochodzenia naszych malowideł — kaplicę św. Katarzyny Sieneńskiej (Zbaraskich) przy kościele Dominikanów w Krakowie. Wkrótce po tym ukazała się wyżej wzmiankowana książka J. Gadomskiego. Ponieważ jednak autor opisuje interesujący nas zabytek w sposób skrócony, należy tu nakreślić streszczenie dziejów ołtarza.

Według Katalogu zabytków kaplica Zbaraskich powstała w latach 1627 1633 „zapewne na miejscu starszej”, jak podaje autor katalogu J. Samek ${ }^{7}$. Chcąc dowiedzieć się, na jakiej podstawie wysnuto to przypuszczenie, zwróciłam się do prof. Samka o wyjaśnienie sprawy. Profesor — za co mu serdecznie

${ }^{4}$ T. Sadziak, jw., s. 3 .

${ }^{5}$ E. Kołodziejska, jw.

${ }^{6}$ T. Sadziak odsłonił kwaterę ze sceną Wymiany serc między św. Katarzynq a Chrystusem, E. Nagaj - scenę Napastowanie św. Katarzyny przez demony. E. Kołodziejska odsłoniła pozostałe kwatery.

${ }^{7}$ Katalog zabytków sztuki w Polsce. T. 4: Miasto Kraków, cz. III 2: Kościoły i klasztory śródmieścia, pod red. A. B o ch na ka i S. S a mka, Warszawa 1978, s. $121 \mathrm{n}$. 
dziękuję - udostępnił mi pracę magisterską zmarłej Barbary Kiszkowskiej ${ }^{8}$, która na podstawie archiwaliów w bardzo przekonywający sposób udowodniła, że w miejscu dzisiejszego nauzoleum Zbaraskich już wcześniej musiała się znajdować kaplica pod wezwaniem św. Katarzyny Sieneńskiej. B. Kiszkowska podaje, że w spisie osób, pochowanych w kościele dominikańskim, wymieniono „szlachetnego Mateusza Krysiewskiego (lub też Brysiewskiego)", którego w roku 1596 „pogrzebiono” w kaplicy św. Katarzyny ${ }^{9}$. Wcześniej zapewne pochowano tu błogosławioną Beatę, zmarłą w roku 1508; o jej grobie pod kaplicą św. Katarzyny znajdują się wzmianki w opisie kościołów krakowskich z roku 1603 i u Bzowskiego w 1606 r. ${ }^{10}$ Była to kaplica prawdopodobnie gotycka, podobna zapewne do sąsiedniej kaplicy św. Magdaleny oraz czterech, oprócz niej, zachowanych przy kościele. Być może, iż w miejscu obecnego nauzoleum Zbaraskich znajdowała się kaplica Piotra Szafrańca, wojewody sandomierskiego, lub Jana, biskupa chełmińskiego. Skądinąd wiadomo, że w roku 1432 kaplice te istniały przy kościele św. Trójcy, lecz nie wiemy, gdzie były doń przybudowane ${ }^{11}$. Jeśli rzeczywiście jedną z nich była owa pierwotna gotycka kaplica, to otrzymała ona później za patronkę św. Katarzynę Sieneńską ${ }^{12}$ i pod tym wezwaniem znana jest na początku XVI w.

Badania Kiszkowskiej pozwalają przypuszczać, że ołtarz z muzeum warszawskiego mógł być pierwotnie ołtarzem głównym kaplicy Zbaraskich. Przypuszczenia te znalazły ostateczne potwierdzenie. W „Roczniku Biblioteki PAU w Krakowie" znajduje się mało znana praca E. Fejkiel ${ }^{13}$ o kościele św. Idziego, od roku 1595 należącym do dominikanów. Autorka omawia tekę Ambrożego Grabowskiego, której zawartość stanowią kopie „dawnych obrazów krakowskich", malowane przez Bogumiła Gąsiorowskiego prawdopodobnie w roku 1868; $\mathrm{z}$ tego bowiem roku pochodzi jedyna wzmianka o jego kontaktach z Grabowskim ${ }^{14}$. W tejże tece, wśród kopii znanych obrazów cechowych,

${ }^{8}$ B. K is zk ow sk a, Kaplica Zbaraskich przy kościele oo. Dominikanów w Krakowie, Kraków 1968 (praca magisterska, Wydział Filozoficzno-Historyczny UJ) Archiwalia cytuję za autorką.

${ }^{9}$ Archiwum Klasztoru oo. Dominikanów w Krakowie: Spis osób pochowanych w kościele oo. Dominikanów w Krakowie (1257-1872).

${ }_{10}$ Necrographia seu obitus fratrum generalium, manuscriptis codicibus facta collectio Anno Domini 161531 iulii, per me fratrem Valerianam Lithuanidem, magistrum Conventus Cracoviensis, „Archiv für Österreichische Geschichte" 4: 1877 s. 143; Kościotów krakowskich opisanie z roku 1603, wyd. Tu row skieg o, Kraków 1869, s. 28; A. B zoviu s, Propago D. Hiacynthi [...] seu de rebus praeclare gestis in provincia Polonia Ordinis Praedicatorum, Venetiis MDCVI, s. 91.

${ }_{1}$ Kodeks dyplomatyczny miasta Krakowa $(1257-1506)$, cz. 2 - 4, Kraków 1882, s. 663; S. To m k ow icz, Kaplice kościoła oo. Dominikanów, „Rocznik Krakowski” 20: 1926 s. 81.

${ }^{12}$ Katarzyna Sieneńska została kanonizowana w roku 1461, dlatego wcześniej nie mogła być patronką wspomnianej kaplicy.

${ }^{13}$ E. Fe j ki el, Nieznane obrazy cechowe z kościoła św. Idziego w Krakowie w akwarelach Bogumita Gąsiorowskiego ze zbioru Ambrożego Grabowskiego, „Rocznik Biblioteki PAU w Krakowie" 12/13:1961/62 s. 109 n. Autorka nie wiedziała o istnieniu tablic ołtarzowych w Muzeum Narodowym w Warszawie.

${ }_{14} \mathrm{~J}$. J arosł a wi eck a - Gąs iorowska, Gasiorowski Bogumit, [w:] Polski stownik biograficzny, t. 7 s. 346 . 
znajdują się cztery sceny z życia św. Katarzyny Sieneńskiej z kościoła św. Idziego w Krakowie, które są kopiami awersów naszego ołtarza z Muzeum Narodowego w Warszawie. Ograniczenie się Gąsiorowskiego do namalowania jedynie awersów ołtarza tłumaczyć można faktem niesłychanie słabego poziomu rewersów w stanie przemalowania. W taki sposób możemy dziś zidentyfikować miejsce pochodzenia naszego ołtarza. Nie jest to jednak, jak się zdaje, miejsce pierwotne. Wiadomo, że w roku 1822 znajdowały się tablice - jeszcze w formie skrzydeł w kościele św. Idziego, o czym świadczy wzmianka w spisie obrazów inwentarza kościoła św. Idziego, umieszczona tuż po notatce o znanym średniowiecznym ołtarzu dominikańskim („Tegoż samego malowania wyobrażającym historyą ś. Katarzyny, trzy łokciowej wysokości, lecz wąskie 2"15). Wydaje się jednak, że podobnie jak ołtarz dominikański zostały one przedtem przeniesione z kościoła dominikanów pod wezwaniem św. Trójcy, z kaplicy św. Katarzyny Sieneńskiej, obecnie - Zbaraskich. Potwierdza to przypuszczenie również wzmianka Z. Hendla i F. Kopery w opisie kościoła św. Idziego: „[...] bogata dekoracja kościoła św. Idziego została skombinowana z resztek pomników i stalli przeniesionych od Dominikanów do tego kościoła z powodu przekształcenia jednej z kaplic XX. Lubomirskich albo Zbaraskich"16.

Kościół św. Idziego zbudowano w pierwszej połowie XIVw. Do 1567 r. pozostawał pod patronatem benedyktynów z Sieciechowa i rodziny Tęczyńskich. W tymże roku Tęczyńscy przekazali połowę prawa patronatu Feliksowi Czerskiemu, sędziemu ziemskiemu krakowskiemu. W roku 1590 opactwo sieciechowskie przelało swe prawa na Uniwersytet Krakowski. Ostatecznie w roku 1595 cały patronat przejęli dominikanie i kościół przebudowali, prawdopodobnie kosztem Tęczyńskich ${ }^{17}$. Ołtarz nasz mógł w tym czasie zostać przeniesiony do kościoła św. Idziego. Dlaczego później trafił do Muzeum Warszawskiego, nie wiadomo.

Życieśw. Katarzyny na tle epoki

Sw. Katarzyna ze Sieny jest jedną z najwybitniejszych postaci niewieścich w historii Kościoła ${ }^{18}$. Urodziła się w Sienie w 1347 roku. Była dwudziestym

${ }^{15}$ Opis, czyli inwentarz kościoła św. Idziego przy ulicy Grodzkiej w Gminie I, sytuowanego, pod opieką i rządem Zgromadzenia księży Dominikanów zostającego, tudzież budowli do tegoż należacych $i$ sprzętów kościelnych. Inwentarz kościoła zakonnego i klasztoru księży dominikanów w Gminie z roku 1822, Kraków (Archiwum oo. Dominikanów w Krakowie, sygn. K. 75). Cytuję za E. Fejkiel.

16 Z. Hende1, F. Kopera, Kościót św. Idziego w Krakowie, Kraków 1905, s. 22.

17 Katalog zabytków sztuki w Polsce. T. 4: Miasto Kraków, cz. III 2: Kościoły i klasztory śródmieścia..., s. 140

18 O życiu i dziełach św. Katarzyny ze Sieny zob.: Enciclopedia italiana, t. 9, Roma 1949, s. 452 -454; Enciclopedia cattolica, t. 3, Roma 1949, s. 1151 - 1158; A. C. O d a s s o, Caterina Benincasa, [w:] Biblioteca sanctorum, t. 3, Roma 1963, s. 1035-1044; M. H. J e t t e, Swięta Katarzyna ze Sieny, przekład J. Mazu r, Warszawa 1979; Sw. Kat arz y na ze Si e n y, Listy, przeklad i przedmowa L. Gry gi el, Poznań 1988; zob. też niżej przypis 20. 
trzecim dzieckiem farbiarza sukna Jacopa Benincasa i jego żony Lapy Piangeti. W wieku siedmiu lat, wbrew zamierzeniom rodziny, ślubowała dziewictwo. Kiedy matka chciała ją wydać za mąż, Katarzyna, aby się zeszpecić obcięła włosy. Gdy ukończyła 16 lat, mimo sprzeciwów rodziny, wstąpiła do III Zakonu dominikańskiego. Należały do niego pobożne niewiasty tzw. mantellate (od włoskiego słowa mantello - płaszcz). Nie były one w ścisłym sensie siostrami i nie żyły wspólnie, nosiły jednak biały dominikański habit z czarną klapą. W takim stanie pozostaje Katarzyna przez trzy lata, mieszkając w swoim domu w odosobnieniu i rozmawiając tylko ze swoim spowiednikiem Rajmundem z Kapui. Po tym okresie wraca do życia społecznego, by służyć bliźnim. Z wielkim poświęceniem opiekuje się biedakami i ludźmi chorymi, zwłaszcza w czasie panującej w 1374 r. zarazy. Nawraca grzeszników. Obok ofiarności odznaczała się siłą umysłu. Wkrótce zebrało się wokól niej grono uczniów różnorakiego stanu i pochodzenia. Byli to ludzie świeccy, a także zakonnicy i duchowni. Oddawali się oni pokucie i miłości bliźniego oraz pomagali Katarzynie w jej pracy społecznej. Grupę tę nazwano „la bella brigata” (piękna drużyna) albo „caterinati” (katarzyńczycy). Wszyscy oni nazywali Katarzynę „la dolce mamma" (słodka matka). Katarzyna prowadziła ascetyczny tryb życia. Jej spowiednik, a zarazem biograf, opowiada, że podczas 50 dni nie przyjmowała żadnych posiłków poza hostią. Pielęgnowała trędowatych i rakowatych. Aby wynagrodzić ją zá jej pełne poświęcenia życie, Chrystus często objawiał się Świętej i zsyłał na nią cudowne zjawiska. Podczas jednego z widzeń pokazał jej ranę w swoim boku i pozwolił jej pić swoją krew. Innym razem, gdy odziała płaszczem biednego, ofiarował jej cudowną suknię, która ludziom była niewidoczna, ale Katarzynę chronić miała od zimna. List apostolski Jana Pawła II na 600. rocznicę śmierci św. Katarzyny ze Sieny potwierdza wielokrotnie dyskutowaną sprawę stygmatyzacji św. Katarzyny, która po raz pierwszy miała miejsce 1 kwietnia 1375 roku w kościele św. Krystyny w Pizie. Życie Katarzyny pełne miłosiernych uczynków, cudów, proroctw i wizji, zyskało jej ogromny rozgłos i popularność u współczesnych. Z głosem Katarzyny liczyły się całe Włochy. Wiele osobistości duchownych i świeckich w najrozmaitszych sprawach, zarówno prywatnych, jak i publicznych, zwracało się do niej po radę. Pozostał po tym ślad w postaci dużego zbioru listów, cennych także pod względem literackim ${ }^{19}$. Trzeba tu zaznaczyć, że święta słabo pisała i czytała, prawdopodobnie więc swoje pisma dyktowała. Poza listami, w latach 1377 - 1378, w przerwach między różnymi zajęciami, Katarzyna podyktowała dzieło, które nosi tytuł Dialog o Bożej Opatrzności ${ }^{20}$. Przedstawiła w nim — jak pisze Jan Paweł II -

${ }^{19}$ L. Grygiel, Przedmowa do: Św. Katarzyna ze Sieny, Listy..., s. 42.

${ }^{20} \mathrm{Sw}$. Kat ar zy na ze Si en y, Dialog o Bożej Opatrzności, czyli Księga Boskiej Nauki, Poznań 1987. Przełożył Leopold Staff, przejrzał i poprawił Wojciech Giertych OP, ostatecznej redakcji dokonal Marcin Bobraj OP na podstawie wydania Giuliany Cavallini (Edizioni Cateriniane, Roma 1980). 
to, „o czym jej dusza w stanie ekstazy rozmawiała z Panem i co wieczna Mądrość powiedziała w odpowiedzi na jej pytania o Kościół, jego członków i cały świat"21. Dzieło to odznacza się duchem prorockim, trzeźwością myśli i jednością wyrazu. Trzecim dziełem Katarzyny są Modlitwy. Niezwykła energia Katarzyny zaprowadziła ją też na drogę działalności politycznej. W tym czasie Kościół przechodził poważny kryzys, związany z przedłużającym się pobytem papieża w Awinionie. W Italii panuje wzburzenie. Florencja i 80 innych miast powstaje przeciwko francuskim legatom papieskim. Grzegorz XI ekskomunikuje Florencję. Florentczycy błagają Katarzynę, aby udała się do papieża. Katarzyna zgadza się na to i przybywa do Awinionu 18 czerwca 1376 roku wraz z 25 członkami „bella brigata”. Tam Katarzyna ustala cel swej podróży do załatwienia trzech najważniejszych potrzeb Kościoła: powrót papieża do Rzymu, doprowadzenie do pokoju w Italii i utworzenie krucjaty dla odebrania Ziemi Świętej Turkom. Za jej wstawiennictwem zawarto pokój z Florencją.

Dnia 13 września 1376 roku Grzegorz XI opuszcza Awinion i wyjeżdża do Rzymu. W Genui Katarzyna nie pozwala mu, gdy chciał zawrócić; potem zaś sama powraca do Sieny. Ale wkrótce śmierć Grzegorza XI (1378) niweczy wszystko. Jego następca, Urban VI, neapolitańczyk, rozpoczyna swój pontyfikat od posunięć, którymi zraża sobie kardynałów francuskich. Oni to, wybierając Klemensa VII, wywołują wielką schizmę Zachodu.

Na prośbę Urbana VI, Katarzyna udaje się do Rzymu, by zorganizować tam opór duchowy, który mógłby położyć kres schizmie. Przed opuszczeniem Sieny, której już nigdy nie ujrzy, dyktuje w ekstazie Dialog — dzieło, które wraz z jej Listami stanowi „skarbiec mistycznej duchowości” — jak pisze jeden z jej biografów. W Rzymie Katarzyna (przy swym słabym zdrowiu wyniszczonym postami) prowadzi ciężkie życie, podzielone między bolesną chorobę, ekstazę i korespondencję, mającą na celu ubłaganie wszystkich wielkich Europy, by przywrócili pokój i jedność Kościoła. Umiera pełna niepokoju o losy Kościoła 29 kwietnia 1380 roku, otoczona swymi uczniami, mając 33 lata. Pochowano ją w Rzymie w kościele Santa Maria sopra Minerwa. Kanonizowana została w 1461 r. przez jej rodaka, humanistę Eneasza Sylwiusza Piccolominiego, który został wybrany papieżem pod imieniem Piusa II. Pius XII ogłosił Katarzynę - obok św. Franciszka z Asyżu - główną patronką Włoch i patronką Rzymu, a Paweł VI ogłosił ją (4 X 1970) doktorem Kościoła.

Ojciec Święty Jan Paweł II wystosował do wiernych w 600. rocznicę śmierci Katarzyny list apostolski, wyżej już cytowany. List ten nie jest odosobnionym polonicum w historii życia świętej. Ważną dla Katarzyny sprawą była idea utworzenia krucjaty dla uwolnienia Ziemi Swiętej od niewoli tureckiej. W zagadnieniach polityki XIV wieku sprawa ta była nie tylko spełnieniem pragnień

${ }^{21}$ List apostolski do biskupów, kapłanów i wiernych Włoch $w 600$. rocznice śmierci św. Katarzyny ze Sieny, dziewicy i doktora Kościoła, „L'Osservatore Romano” $1980 \mathrm{nr} 11$. 
wierzących chrześcijan, ale także aktem rozumu politycznego, ponieważ odpychano w ten sposób Turków od granic Europy ku ich właściwym siedzibom. I ten problem stara się Katarzyna jakoś rozwiązać. W roku 1373 pisze list do Elżbiety Łokietkówny ${ }^{22}$, w którym zaklina Elżbietę, aby użyła wpływu na swego syna Ludwika Węgierskiego i zachęciła go do zaciągnięcia się w szeregi krzyżowców. Drugi list w tej samej sprawie w roku 1375 pisze Katarzyna do samego Ludwika Węgierskiego, kiedy był on już królem polskim ${ }^{23}$. Zachowały się też wzmianki o kontaktach królowej Jadwigi ze spowiednikiem Katarzyny Rajmundem z Kapui ${ }^{24}$. Istniały również liczne powiązania Polski z Eneaszem Sylwiuszem Piccolominim, późniejszym papieżem Piusem II, który przyczynił się do kanonizacji św. Katarzyny ${ }^{25}$.

\section{Sw. Katarzyna w literaturze i sztuce}

We Włoszech głównym biografem świętej był bł. Rajmund z Kapui, dominikanin, później generał zakonu dominikanów. Jego to wyznaczają przełożeni dominikańscy na stałego spowiednika Świętej. Od roku 1374 towarzyszy jej we wszystkich podróżach, pomaga w trudnych misjach politycznych i akcjach apostolskich. Spod jego pióra wyszedł w roku 1393 łaciński życiorys Katarzyny, wydany potem drukiem we Florencji w 1477 r. Lexico der Christliche Ikonographie (por. przypis 35) podaje, że tekst Rajmunda pisany był w latach 1385 - 1395. Była to tzw. Legenda maior w odróżnieniu od Legenda minor Tomasza Caffariniego (pierwsza wersja 1412 - 1413, druga wersja 1414) i innych krótszych pism, poświęconych Katarzynie przez jej uczniów i wielbicieli. Caffarini opracował także suplement $(1411-1418)$, gdzie zgromadził materiały opuszczone przez Rajmunda, głównie opisy cudów i wizji znanych pierwszym spowiednikom Swiętej: Tomaszowi della Fonte i Bartłomiejowi Dominici. Cennym pismem jest także rękopis znany pod nazwą Cuda, napisany przez anonimowego pisarza w roku 1374 podczas pobytu św. Katarzyny we Florencji. Inni uczniowie Katarzyny, m. in. Pagliaresi, Jacopo del Pecora, Anastiasio da Montalcino, Gugliemo d'Inghliterra, także piszą pisma i wiersze na cześć Swiętej26. Życiorys napisany przez Rajmunda z Kapui pozostaje jednak do dziś najbardziej obiektywnym i całościowym portretem św. Katarzyny ${ }^{27}$.

${ }^{22} \mathrm{H}$. Pol a cz k ów na, Św. Katarzyna Sieneńska a Elżbieta Łokietkówna, „Szkoła Chrystusowa" $10: 1935$ z. 5 s. 298; Sw. K at a r zy n a ze Sien y, Listy..., s. 93.

${ }^{23}$ M. D y now sk a, Św. Katarzyna Sieneńska w literaturze polskiej, Lwów 1936, s. 1; H. Pola c zkówn a, Św. Katarzyna Sieneńska a Ludwik, król Węgier i Polski, Lwów 1936; Św. Ka t arzyna ze Sieny, Listy..., s. 352.

${ }^{24} \mathrm{P}$. K i l l a r, Powstanie studium generalnego w Krakowie, [w:] Studia nad historiq Dominikanów w Polsce, pod red. J. Kłoczowskiego, s. 352.

${ }^{25}$ I. Za ręb b k i, Stosunki Eneasza Sylwiusza Piccolominiego z Polska, „Rozprawy Wydziału Historyczno-Filozoficznego Polskiej Akademii Umiejętności” 70 : 1939 s. 281 — 473.

${ }^{26}$ Enciclopedia cattolica, t. 3 s. 1155.

${ }^{27}$ L. Grygiel, Przedmowa do: Sw. Katarzyna ze Sieny, Listy..., s. 12. 
Wobec tak wielu w Italii wczesnych źródeł pisanych do życia św. Katarzyny dziwi zupełny brak tych źródeł w Polsce do momentu pojawienia się naszego ołtarza. Mimo kontaktów Katarzyny, jej spowiednika oraz Piusa II z członkami dworu polskiego do początku XVI wieku, to jest do czasu powstania ołtarza, nie ma prawie żadnych śladów kultu św. Katarzyny Sieneńskiej w Polsce ${ }^{28}$. Wymownym tego wyrazem są - jak już wspomniałam - wyniki przeprowadzonej przeze mnie kwerendy, która wykazała, że w całej Małopolsce nie ma wezwań kościelnych tej Świętej, oprócz jednego omawianego przeze mnie obiektu. Jeśli idzie o źródła pisane, pierwszym biografem polskim Katarzyny był Piotr Skarga ${ }^{29}$. Rok 1579, w którym zostały po raz pierwszy wydane $\dot{Z} y w o$ ty świętych Skargi, możemy uważać na pierwsze źródło literackie w piśmiennictwie polskim ${ }^{30}$. Skarga, pisząc żywot św. Katarzyny, wykorzystał Legendę maior Rajmunda z Kapui oraz Legendę minor Tomasza Caffariniego. Wkrótce potem (1609) ukazal się skrócony nieco przekład Legendy Rajmunda, opracowany przez Szymona Wysokiego ${ }^{31}$. Z innych późnych źródeł wymienić należy wydaną w Krakowie w 1843 r. książeczkę zatytułowaną: Żywot przedziwny św. Katarzyny Sieneńskiej z zakonu św. Dominika z dodatkiem godzinek... do tejże Swiętej ${ }^{32}$. Ostatnim źródłem opartym na tłumaczeniu dzieła Rajmunda z Kapui jest Żywot św. Katarzyny, wydany w Krakowie w 1880 r. ${ }^{33}$

Analizując ikonografię naszego ołtarza, opieram się o to ostatnie źródło w związku z większą czytelnością tekstu. Równie skąpe do połowy XVI w., nie tylko w Polsce, ale i na zachodzie, na północ od Alp. są przedstawienia św. Katarzyny Sieneńskiej w sztuce. Künstle wymienia zaledwie dwa przykłady: rzeźbione popiersie Swiętej z warsztatu Mikołaja z Lejdy i fresk z XVI wieku w klasztorze Dominikanów w Gebweiler w Alzacji: św. Katarzyna otrzymuje od Chrystusa koronę cierniową ${ }^{34}$. W Lexikon der christlichen Ikonographie znajdują się jeszcze dwa przykłady: cykl ilustracji do legendy (rysunki piórkiem, Augsburg 1466) i także cykl drzeworytów H. Schäufeleina z r. $1515^{35}$. L. Reau tłumaczy to ograniczenie faktem, że Święta urodziła się zbyt późno, aby zostać

28 Ostatnio J. Gadomski (jw., s. 62, 129) przypomniał znane Walickiemu i Dobrowolskiemu przedstawienie Świętej, pochodzące z roku jej kanonizacji (1461). Jest to jedyny, obok naszego ołtarza, przykład przedstawienia Swiętej w Polsce w okresie XV - XVI w.

${ }_{29}$ P. S k a rg a, Żywoty świętych Starego i Nowego Zakonu..., Kraków 1579, s. 355 - 361.

${ }^{30}$ M. Dynowska, jw., s. 2 .

${ }^{31} \mathrm{R}$ a i mu ndus de Ca pua, Żywot przedziwny świętey dziewice Katarzyny Seneńskiej [...] $z$ taciny na polskie przez X. Szymona Wysockiego Soc. Jesu przetożony y potrosze skrócony, Kraków 1609.

${ }^{32}$ M. D ynowska, jw., s. 11.

33 Żywot przedziwny dziewicy Katarzyny Seneńskiej panny seraficznej zakonu ojca św. Dominika przez W. O. Rajmunda Kapuana generała zakonu Kaznodz. natenczas spowiednika tej świętej panny napisany i od niegoż „Teologia Historycznq" nazwany [...] z tacińskiego na polski język przez X. Szymona Wysockiego wydany w 1609 in 8-vo, a teraz z powodu 500-letniej rocznicy zejścia tej św. Panny [...] staraniem W. O. Wincentego Maryi Podlewskiego, przeora klasztoru krakowskiego powtórnie wydany w Krakowie 1880 r., Kraków 1880.

${ }_{34}$ K. K ü n st le, Ikonographie der Christlichen Kunst, t. 2, Freiburg i. Br. 1926, s. 375 - 378.

${ }^{35}$ Lexicon der christlichen Ikonographie, München 1974, s. $302-306$. 
patronką jakiegoś cechu i jej przedstawienia są popularyzowane tylko przez dominikanów i pojawiają się sporadycznie tylko w kościołach i klasztorach dominikańskich ${ }^{36}$.

Inaczej ma się sprawa w ojczyźnie Swiętej, we Włoszech ${ }^{37}$. Przedstawienia Swiętej są tam bardzo liczne i pojawiają się wcześnie. Malowało ją wielu wybitnych malarzy: w XV wieku - Giovanni di Paolo (kilkakrotnie), Vecchietta, Mateo di Giovanni; w XVI wieku - Perugino, Crespi, Sodoma. Najwcześniejszym przykładem jest malowidło ścienne z XVI w. w Capella delle Volte w Sienie, wykonane przez Andrea Vanni (il. 9). Niektórzy badacze uważają, że zostało wykonane jeszcze za życia Swiętej. Drugim wczesnym przykładem jest malowidło szkoły pizańskiej z r. 1385: Mistyczne zaślubiny św. Katarzyny (Pisa, Muzeo Civico). Najwięcej przedstawień pojawiło się w rodzinnej Toskanii. Istnieją tam ok. 24 przedstawienia pojedyncze i 2 cykle przedstawieniowe. Ogólnie istnieje we Włoszech 5 cyklów przedstawieniowych: w Mediolanie, w kościele S. Maria delle Grazie freski Giovanniego Donato da Montefrano (1490); w Genui, w kościele S. Maria di Castello freski szkoły liguryjskiej (XV wiek); w Rzymie, w kościele S. Sisto Vecchio fresk szkoły z Lacium (XV wiek); w Sienie, w Muzeum, cykl Domenico Beccafumi, cykl rysunków Giovanniego di Paolo, obecnie w Brukseli (Stoclet Collection). Cztery cykle - jak już mówiłam - pochodzą z terenu Niemiec.

$\mathrm{W}$ świetle tego materiału nasz ołtarz jest jednym $\mathrm{z}$ dziewięciu znanych wczesnych cyklów przedstawieniowych i jednym z pięciu poza Alpami, co jest wymownym dowodem wartości zabytku. Nie udało się dotąd odnaleźć analogii formalnych do naszych malowideł. Sceny pokrewne ikonograficznie krakowskim malowidłom są skomponowane w inny sposób. Tak przedstawia się sprawa w scenach: scena Oddanie ptaszcza żebrakowi (szkoła toskańska z XV w.); scena Oddawanie serca Chrystusowi, malowana w XV w. przez Guidoccia Cozzarelli XV w.; scena Oddawanie serca Chrystusowi (szkoła toskańska XV w.); Chrystus udziela Komunii św. Katarzynie, obraz malowany przez Diovanniego di Paolo, obecnie Nowy York (Metropolitan Museum); Chrystus udziela Komunii (szkoła umbryjska XV w.), Spoleto, kościół S. Domenico ${ }^{38}$. Przeglądając materiał z innych rejonów nie znalazłam ikonograficznych analogii. Malowidła krakowskie mają swój określony ikonograficzny „scenariusz”: jest nim Legenda maior Rajmunda z Kapui. Przedstawienia malarskie krakowskiego pochodzenia ilustrują wiernie tekst Legendy często kumulując dwa lub więcej epizodów z życia Świętej w jednym obrazie.

${ }^{36}$ L. Ré a u, Iconographie des saints, A-F, Paris 1958, s. $272-277$.

${ }^{37} \mathrm{G}$. K a f t a l, Iconography of the saints in Tuscan painting, Firenze 1952, s. 236-248; tenże, Iconography of the Saints in Central and South Italian Schools of Painting, Firenze 1965, s. $270-$ 274; tenże, Iconography of the saints in the painting of north east Italy, Firenze 1978, s. $202-203$; tenże, Iconography of the saints in the painting of north-west Italy, Firenze 1985, s. 192 - 195.

38 Tamże, il. 261 (Toskania), il. 264 (Toskania), il. 265 (Toskania), il. 274 (Toskania), il. 297 (Włochy środkowe). 


\section{Opis ikonograficznych malowidet dominikańskiego ottarza św. Katarzyny}

Po konserwacji ołtarza można zrekonstruować dawny układ kwater ${ }^{38 a}$. Nie zawsze są one równe kolejności zapisu legendy, w całości jednak prawie całkowicie ją ilustrują. Część środkowa ołtarza zaginęła. Wątek malowideł przebiega od górnej kwatery rewersu lewego skrzydła, poprzez kwaterę dolną rewersu lewego skrzydła, następnie przenosi się na górną kwaterę rewersu prawego skrzydła i dolną kwaterę tegoż rewersu, po czym przechodzi na awersy: lewe skrzydło kwatera górna, lewe skrzydło kwatera dolna, prawe skrzydło kwatera górna, prawe skrzydło kwatera dolna.

Pierwszym przedstawieniem, otwierającym dzieje życia Katarzyny, jest scena Umartwienia św. Katarzyny w górnej kwaterze rewersu lewego skrzydła (il. 5). Przedstawia ona Świętą w okresie młodości, przed wstąpieniem do zakonu. Swięta klęczy przed krucyfiksem i biczuje się łańcuchem. Głowę ma owiniętą chustką. Przed Świętą leży otwarta księga. Między Świętą a krucyfiksem leży na (niezidentyfikowanym) sprzęcie biała materia. W głębi na ławie stoi klepsydra. Z lewej strony sceny otwór drzwiowy, na posadzce banderola $\mathrm{z}$ nieczytelnym napisem. Scena ta jest najbogatsza treściowo; połączono w niej kilka fragmentów legendy i dodano elementy symboliczne. Tekst legendy, na którym wzorowano przedstawienie, tak omawia ten epizod: „Albowiem gdy jednego czasu modliła się przed krucyfiksem, stary nieprzyjaciel [diabeł] wrzucił się w pośrodek, szatę jedwabną w ręku mając i gotując się do odzienia panny w oną szatę, która aczkolwiek nim wzgardziła i z niego się naśmiała, żegnając się krzyżem św. i do ukrzyżowanego się obracając, jednak on, gdy zniknął, tak wielką tam pokusę do marności ubiorów zostawił, iż jej umysł niepomału był zatrwożony. Lecz natychmiast wspomniawszy sobie na przedsięwzięcie panieńskie, tak do oblubieńca swego mówiła: Najsłodszy oblubieńcze mój ty wiesz, iż mimo Ciebie, żadnegom nigdy oblubieńca nigdy nie pożądała, racz mię wspomódz, abym te pokusy w imię święte Twoje zwyciężyła”. Wkrótce ukazała się jej Matka Boska i odziała ją w piękną szatę, mówiąc: „Wiedz córko, iż szaty, które z boku Syna mego pochodzą, wszystkie insze szaty w śliczności i piękności przechodzą" ${ }^{39}$. Dalszy komentarz do tej sceny istnieje w legendzie: „chcąc naśladować Ojca św. Dominika, który się jej ukazał, łańcuchem żelaznym trzykroć codzień dyscyplinę czyniła"40.

Znany fakt obcięcia włosów znajduje taki opis w legendzie: „A gdy to uczyniła już niejako przedtem, ale wedle Apostolskiej nauki, zzawinąwszy się chodziła [...]. Co gdy najprzód matka zobaczyła przyczyny zawicia tego dociec chciała, ale odpowiedzi jasnej mieć nie mogła, dlatego, iż gdy panna św. ani

38a Wymiary kwater są niejednolite. Skrzydlo lewe kwatera górna - 77,5 x 59, kwatera dolna

-77 x 58,5 cm. Skrzydło prawe, kwatera górna - 75,5 x 56, kwatera dolna - 78,5 x 59,5 cm.

39 Żyot przedziwny..., s. $357-358$.

40 Tamże, s. 36. 
skłamać, ani też z prawdą otworzyć się jawnie natenczas nie chciała, raczej szepcząc, a niżeli mówiąc, odpowiedź dawała. Ale ona przystąpiwszy ku niej, z głowy zawicie zrzuciła i to czego się nigdy nie spodziewała, gdy natenczas ujrzała, $\mathrm{z}$ wielkim żalem i z lamentem serdecznym dla włosów iż były bardzo śliczne rzecze: Ach córko cóżeś to uczyniła? Ale panna zakrywszy zaś głowę, stamtąd odeszła"41. Stąd w pierwszej scenie chusta na głowie Swiętej.

Oprócz tych nawiązań do legendy Rajmunda z Kapui, scena pierwsza zawiera jeszcze dwa elementy symboliczne, które pozwalają zaliczyć tę scenę do przedstawień typu „Vanitas” typu, który obrazuje ideę marności świata. U początku tych przedstawień leży werset ze Starego Testamentu: „Marność nad marnościami rzekł Ekklesiastes: marność nad marnościami, i wszystko marność” (Eccles. 1, 2). „Vanitas vanitatum” — oto skrócona forma idei Eklezjasty. Dowiadujemy się stamtąd, że tematyka śmierci w sztuce, istniejąca od wieków, w gotyku przybierająca formę makabrycznych tańców śmierci, w okresie renesansu przybiera inny sposób obrazowania. „Istnieje wiele sposobów sugerowania tej idei. Nie ukazując śmierci [...], można przecież pokazać dosłownie lub metaforycznie przemijanie istot żywych [...]. Popularnymi w emblematyce renesansowej i manierystycznej znakami vanitas stały się obrazy dymu, wiatru, szybko więdnących kwiatów, latwo gasnącej świecy"42. Do tego typu przedstawień należy również klepsydra. Właśnie klepsydrę odnajdujemy w scenie pierwszej cyklu malowideł krakowskich. Uzupełnia ją nieczytelny napis na banderoli. Napisy podobne, uzupełniające przedstawienie idei śmierci, odnajduje się często w przedstawieniach vanitas. Mają one formę krótkiej maksymy: „Mors omnia vincit”, „Memento mori”, „Hodie mihi, cras tibi”. Jednym z najwcześniejszych przykładów nowej ikonografii był medal Giovanniego Boldù z r. 1458 (il. 10), który przedstawia z lewej strony siedzącego młodzieńca $\mathrm{z}$ twarzą ukrytą $\mathrm{w}$ dłonaich, z prawej - putto trzymające płomień w ręku i wsparte na wielkiej czaszce. Napis u góry medalu brzmi: „Io son fine”. Takie i podobne wyobrażenia dziecka z czaszką, klepsydrą i napisem mnożą się w XVI wieku (np. il. 11: drzeworyt włoski z napisem „L’hora passa”). Przykłady tego mamy również w Polsce: w kościele Dominikanów w Krakowie podobną formę ma nagrobek Rafała Ocieskiego (il. 12; po 1547), w kaplicy Firlejów w Bejscach z przełomu XVI i XVII wieku wyobrażono dziecko z czaszką i klepsydrą (il. 13). Przedstawienie klepsydry i napisu towarzyszące Swiętej w malowidle naszego ołtarza jest najwcześniejszym na terenie Polski wyobrażeniem vanitas.

Dalszy tok malarskiej ilustracji legendy (kwatera dolna rewersu prawego skrzydła) przedstawia św. Katarzynę przed wstąpieniem do zakonu, kiedy uka-

${ }^{41}$ Tamże, s. 21.

$42 \mathrm{~J}$. B i a ł o s to ck i, Vanitas, z dziejów obrazowania idei „marności” $i$,przemijania” w poezji i sztuce, [w:] Teoria i twórczość, Poznań 1961, s. 105 n. 
zuje się jej św. Dominik i pokazując szaty zakonne, obiecuje rychłe wstąpienie Katarzyny do zakonu (il. 6). Obie postacie znajdują się we wnętrzu kościelnym. W tle, w oddzielnym wnętrzu (prezbiterium lub kaplica), znajduje się mały rzeźbiony tryptyk. Sklepienie $\mathrm{z}$ widocznymi żebrami gotyckimi. Kaplica oddzielona od wnętrza kościoła łukiem w kształcie oślego grzbietu, w ścianach kaplicy okna gotyckie. W prawej ścianie kaplicy portal prowadzący do wyjścia z kościoła - w oddali widoczny mały domek. Ten element wskazywałby raczej, że jest to kaplica z osobnym wyjściem, a nie prezbiterium. Nad portalem rozeta. Podobne rozety w ścianie oddzielającej kaplicę od wnętrza kościoła. Według opisu legendy, scena ta ma taki przebieg: „Widzenie we śnie miała ojców świętych różnych zakonów fundatorów między nimi ujrzała Dominika św. [...] Ona niewiele myśląc, zaraz ku św. Dominikowi się obróciła i gdy już szła ku niemu zobaczyła iż Ojciec św. ku niej się pospiesza i na jednej ręce zakonniczek swoich habit trzyma, przystąpiwszy tak rzecze do niej: Bądź umysłu stałego córko najmilsza, a wszelkich przeszkód się nie obawiaj boć zapewne powiadam, iż w odzienie takie, którego dawno pragniesz, niedługo obleczona będziesz" 43 .

Kwatera pierwsza rewersów na skrzydle prawym u góry jest trudna do pełnego wyjaśnienia, ponieważ została nadpalona po stronie lewej od widza. Została tu jedynie postać Swiętej z prawą ręką uniesioną w górę i wyciągniętym palcem wskazującym. Po prawej stronie, w oddzielnym wnętrzu przedstawiona symultanicznie postać Katarzyny przy łóżku, na którym leżą dwie postacie. Być może jest to całościowe przedstawienie ilustrujące 4. rozdział legendy, zatytułowany: O sprawach przedziwnych, które czyniła, chorych opatrując i ustugujac ${ }^{44}$.

Kwatera dolna na rewersie prawego skrzydła przedstawia w jednej scenie dwa epizody: Katarzyna oddaje swa szatę żebrakowi (il. 8), a następnie ukazuje się jej Chrystus, obdarzając ją szatą i mówiąc, że jest to szata, która „ludziom będzie niewidoczna, ale tobie [Katarzynie] rzeczywista, którą tak dusza, jako i ciało twoje od zimna szkodliwego obronione będzie" 45 . Scena przedstawia dwie postacie, w głębi portal gotycki z widocznym pejzażem, po prawej okno, w rogu prawym klęczy żebrak.

Sceny awersów rozpoczyna przedstawiona na lewym awersie u góry postać Katarzyny i Chrystusa w momencie, gdy Swięta przykłada usta do boku Chrystusa, by pić Jego krew (il. 1). W lewym od widza, górnym rogu kwatery postać anioła. Scena ta jest znowu ilustracją dwu epizodów z życia Katarzyny. Dla umartwienia Katarzyna wypiła wodę, w której obmywała cuchnący wrzód chorej kobiety: „Dnia tego jednego, gdy on straszliwy wrzód odkryła, aby go umywszy ochędożyła, natychmiast tak wielki i tak okrutny cuch z niego wypadł, nie

\footnotetext{
43 Żywot przedziwny..., s. 26.

44 Tamże, s. $120-149$.

45 Tamże, s. $111-114$.
} 


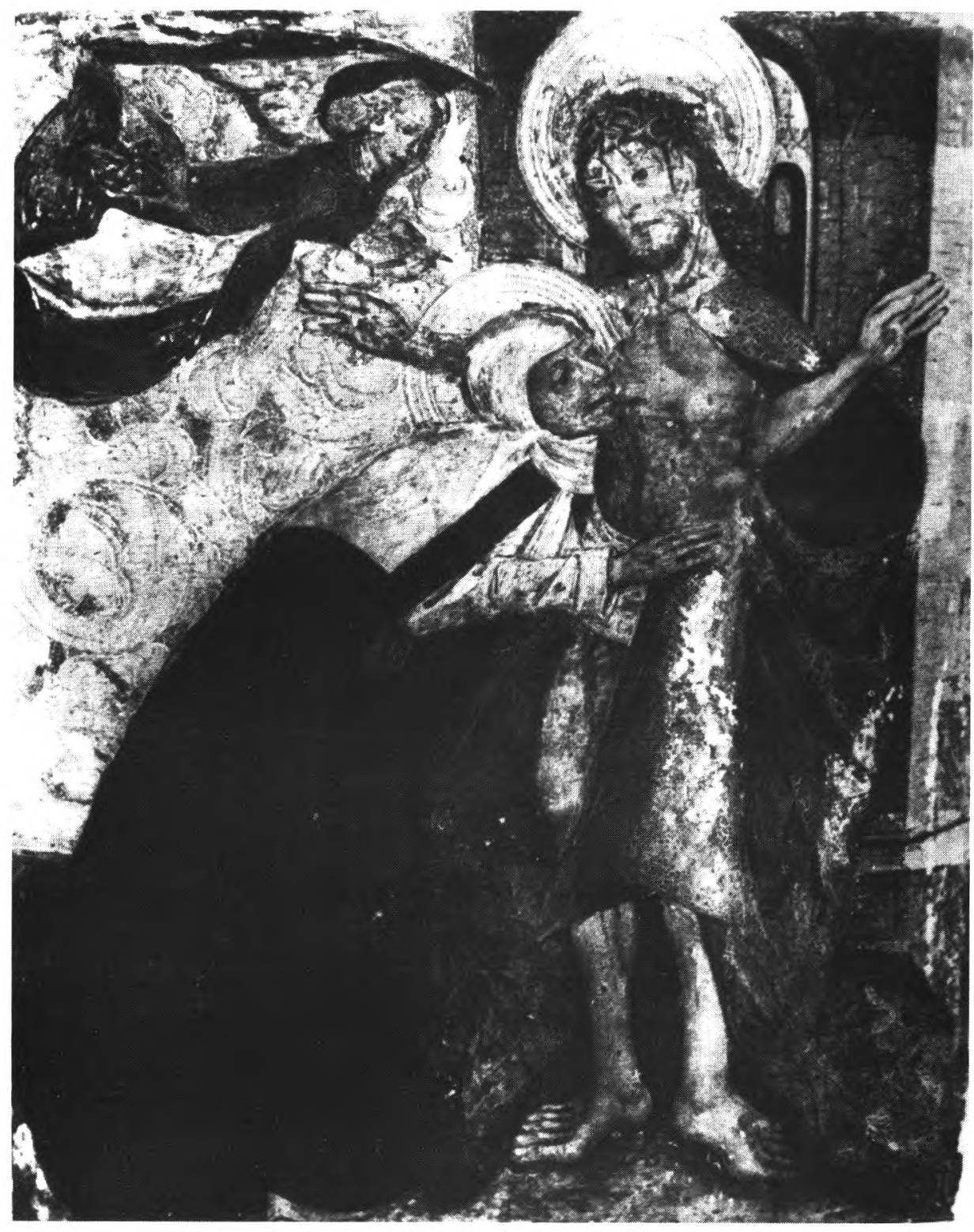

1. Święta Katarzyna pijąca krew z boku Chrystusa, awers, kwatera górna lewego skrzydła oltarzowego. 


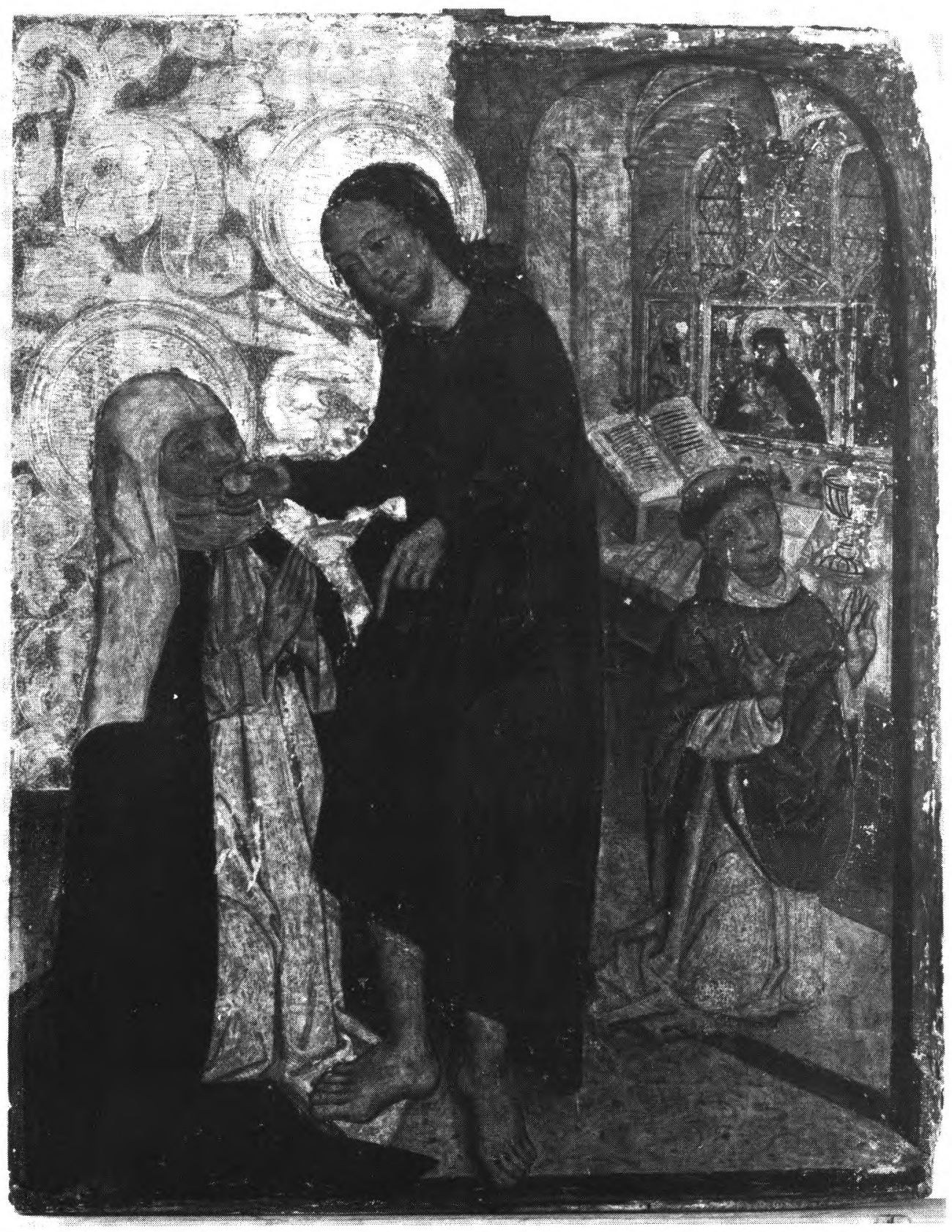

2. Chrystus udziela komunii św. Katarzynie, awers, kwatera dolna lewego skrzydła ołtarzowego. 


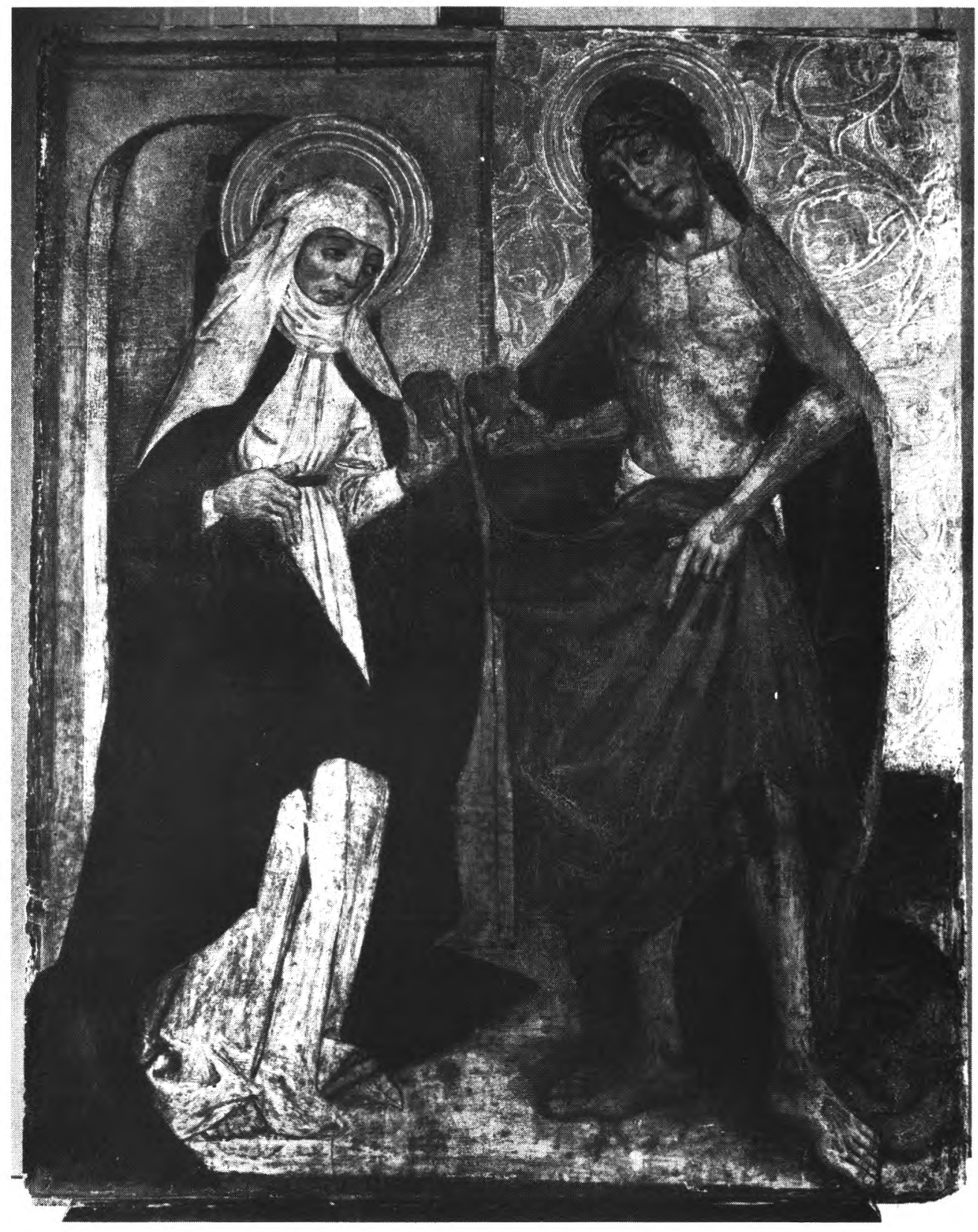

3. Wymiana serc między św. Katarzynq a Chrystusem, awers, kwatera górna prawego skrzydła oltarzowego. 


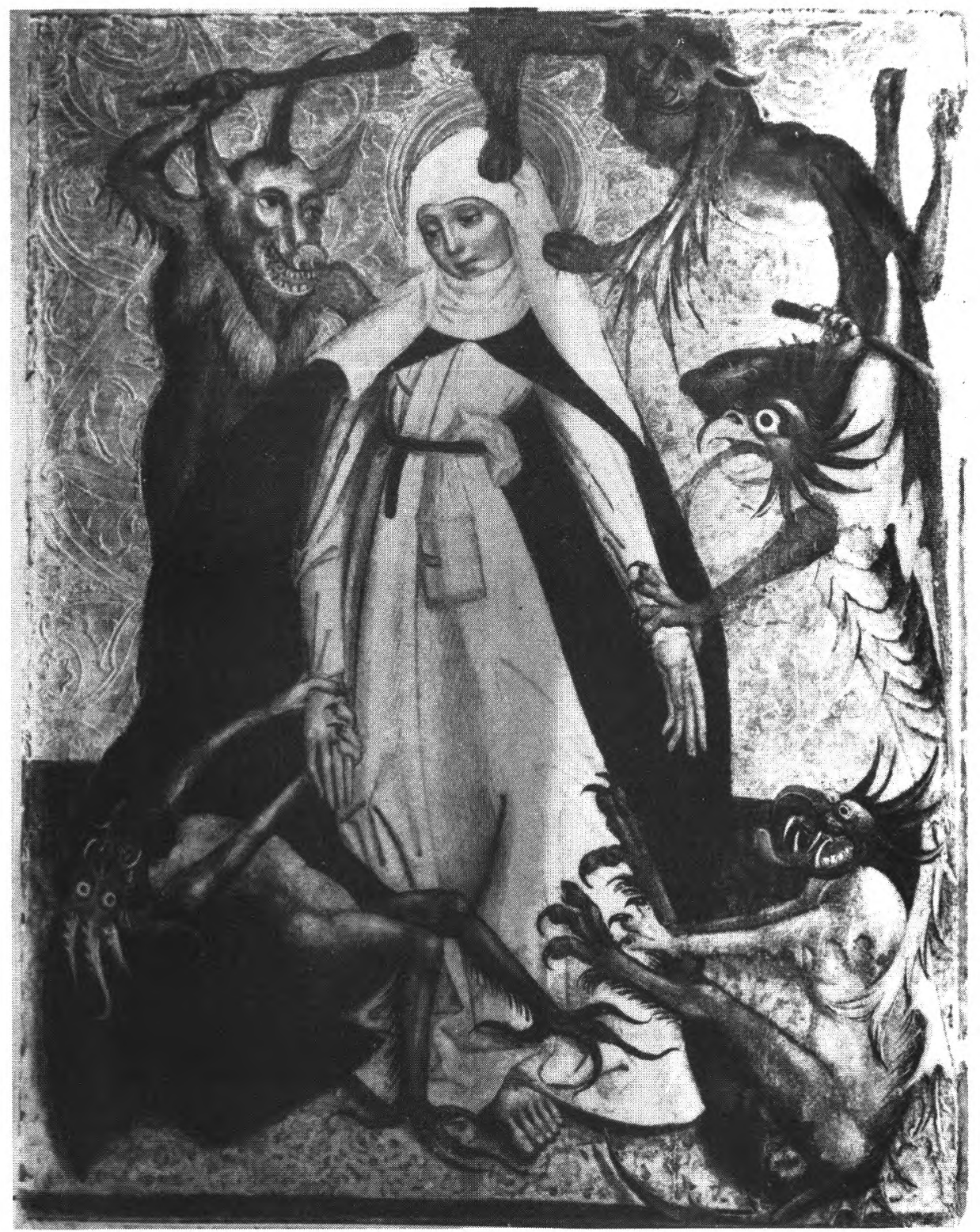

4. Sw. Katarzyna napastowana przez demony, awers, kwatera dolna prawego skrzydła ołtarzowego. 


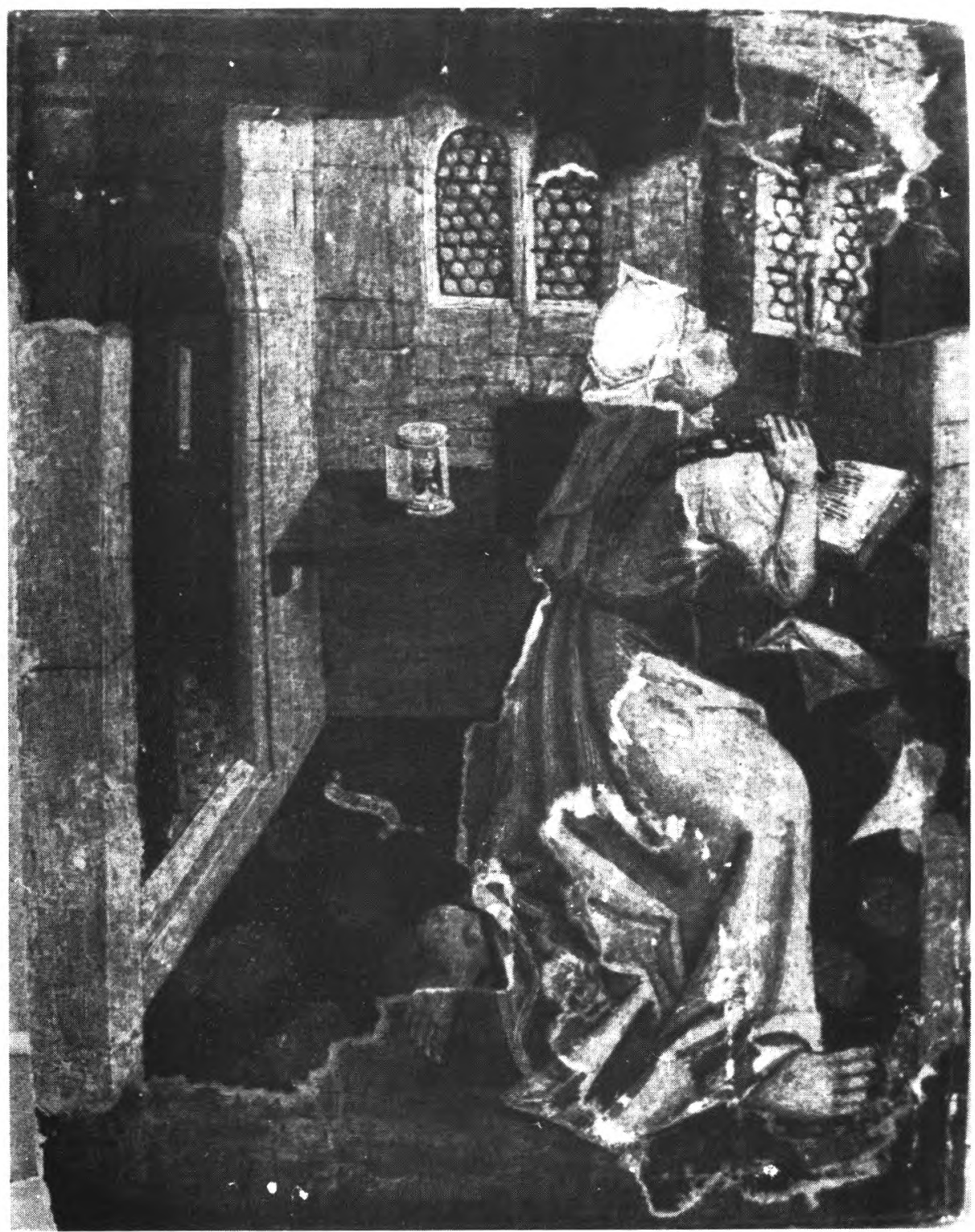

5. Umartwienia św. Katarzyny, rewers, kwatera górna lewego skrzydła ołtarzowego. 


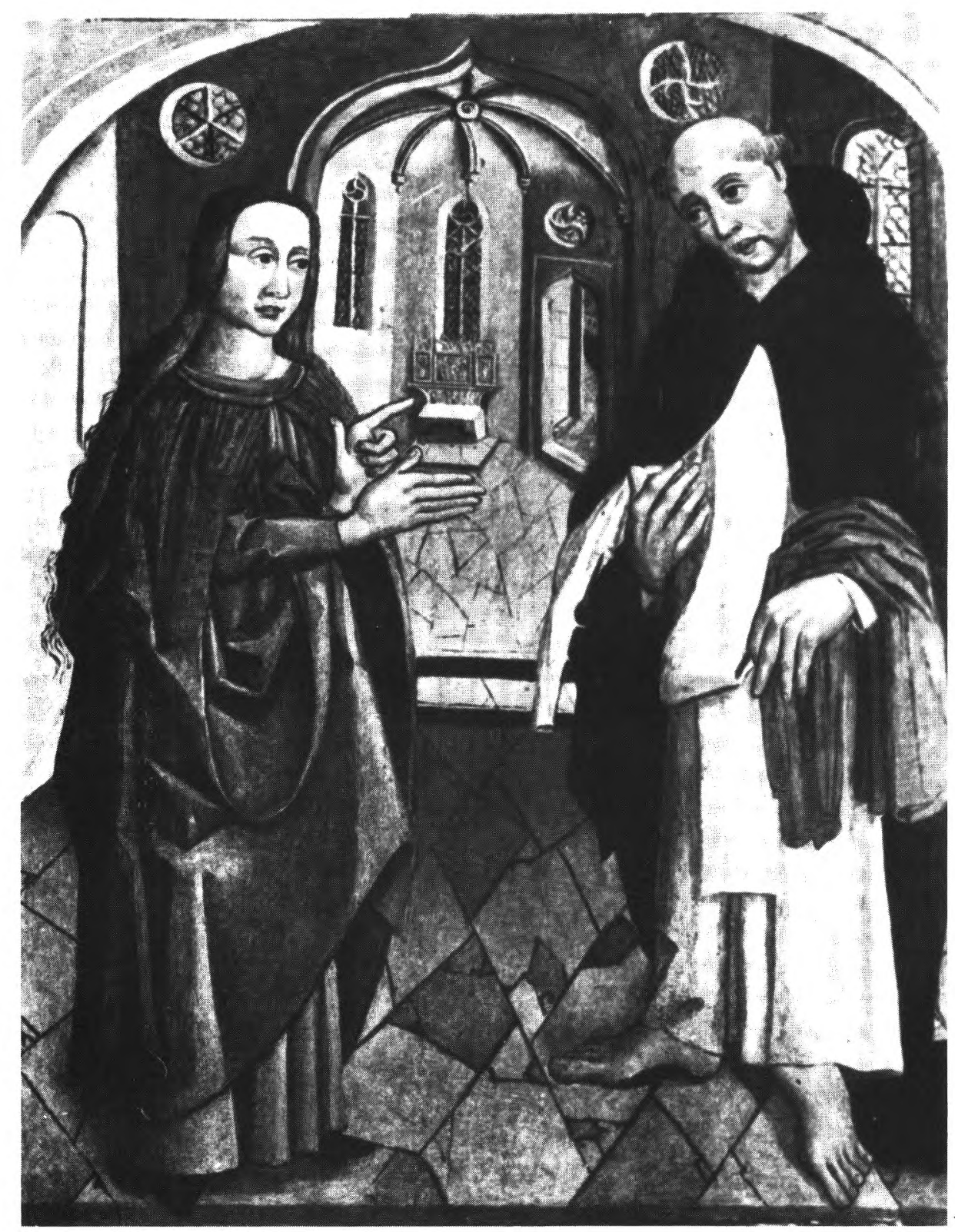

6. Św. Katarzyna ześw. Dominikiem, rewers, kwatera dolna lewego skrzydła ołtarzowego. 


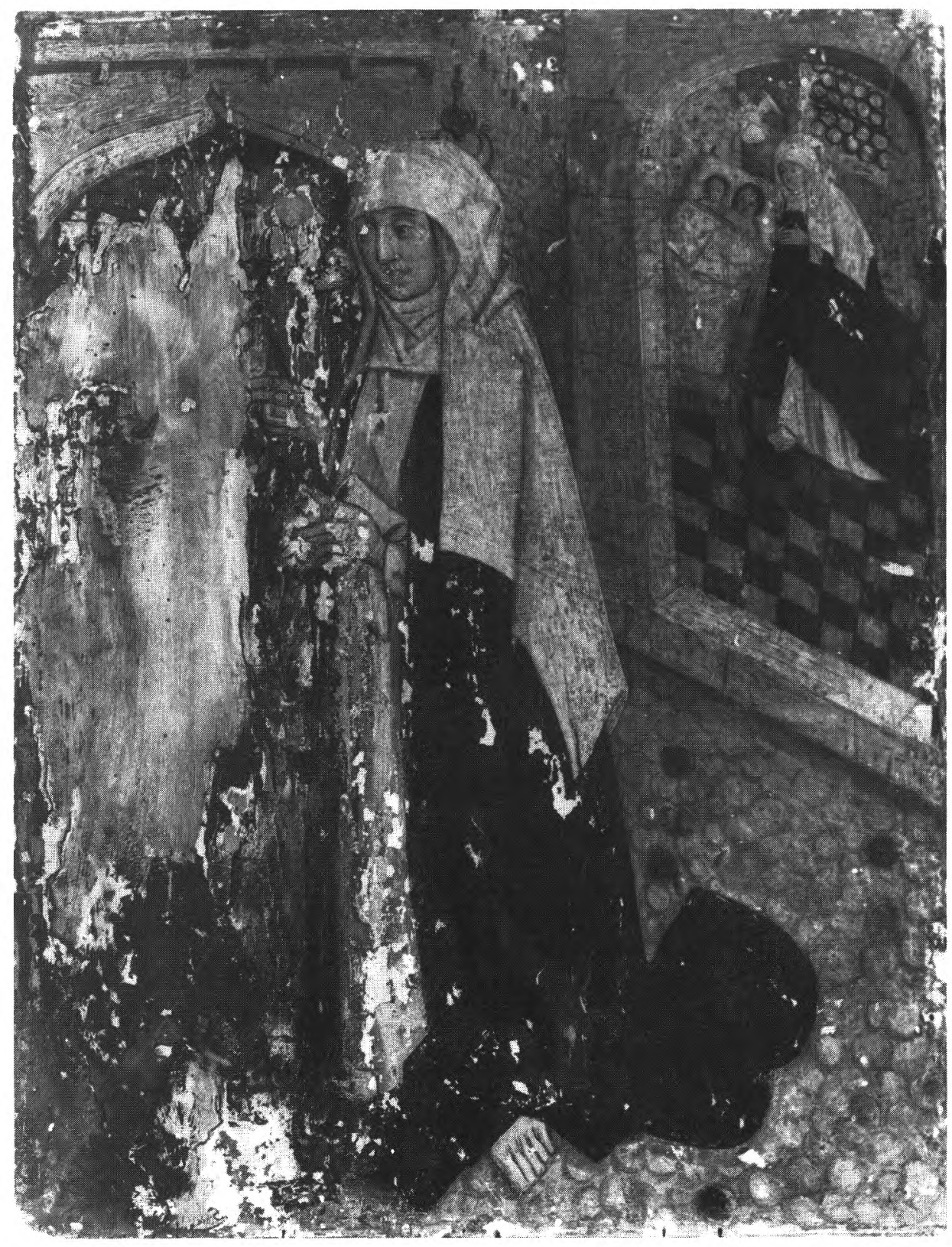

7. Sw. Katarzyna leczy chorych, rewers, kwatera górna prawego skrzydła ołtarzowego. 


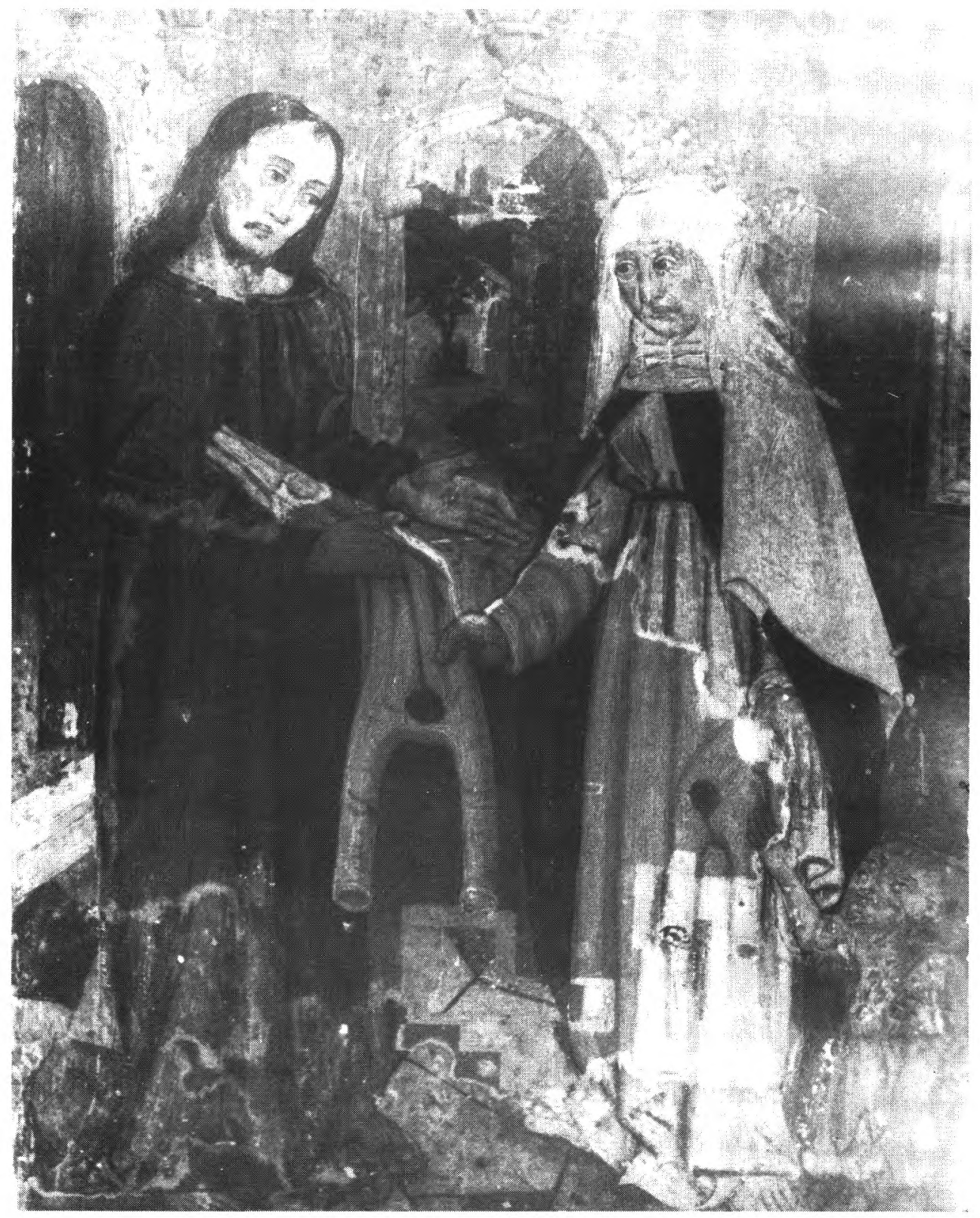

8. Sw. Katarzyna obdarzona ptaszczem przez Chrystusa, rewers, kwatera dolna prawego skrzydla oltarzowego. 


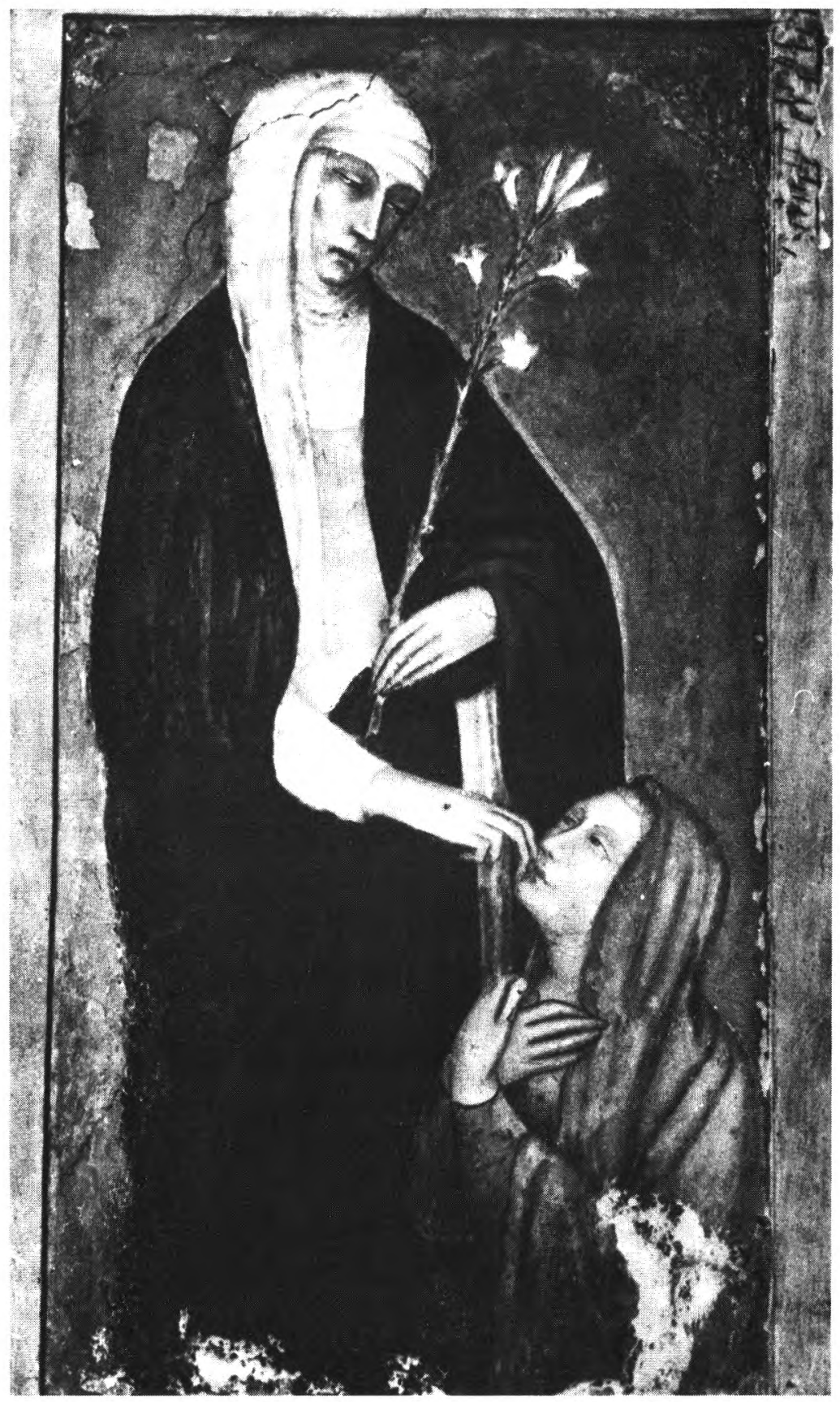

9. Sw. Katarzyna, malowidło ścienne w Capella della Volte, bazylika Św. Dominika w Sienie, ok. $1380-1390$. 


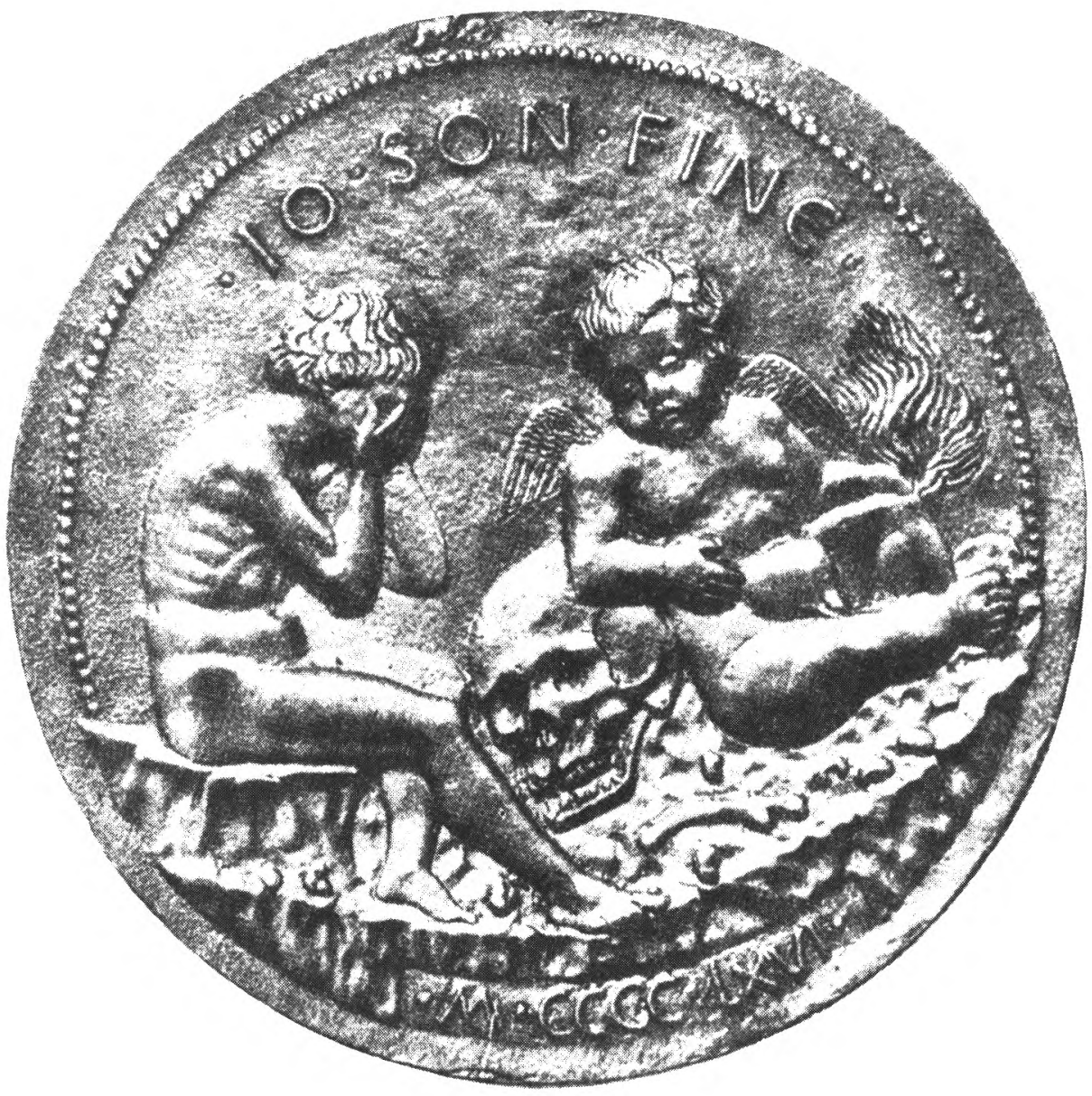

10. Medal Giovanniego Boldù, 1458. 


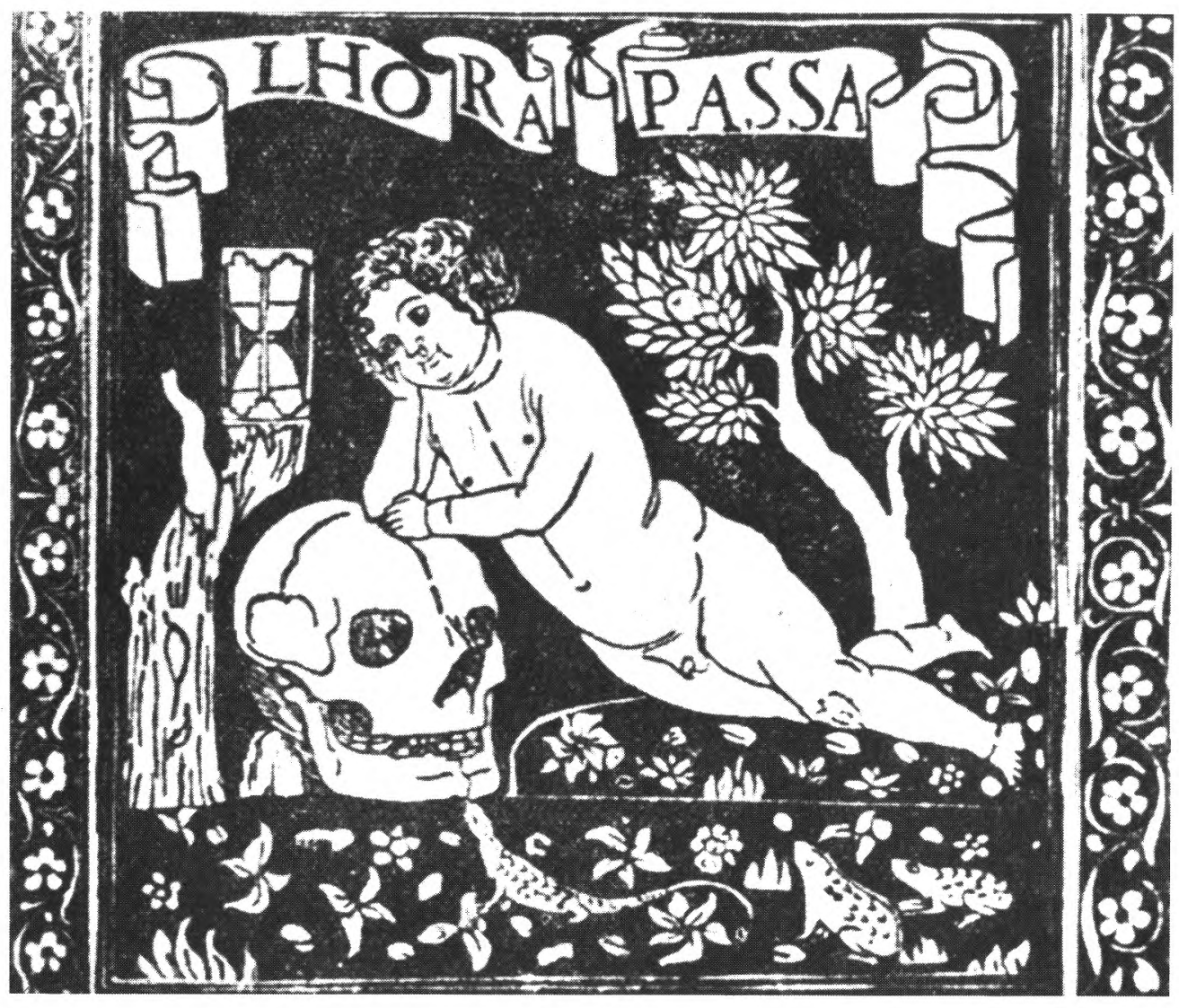

11. Drzeworyt włoski, XVI w. 


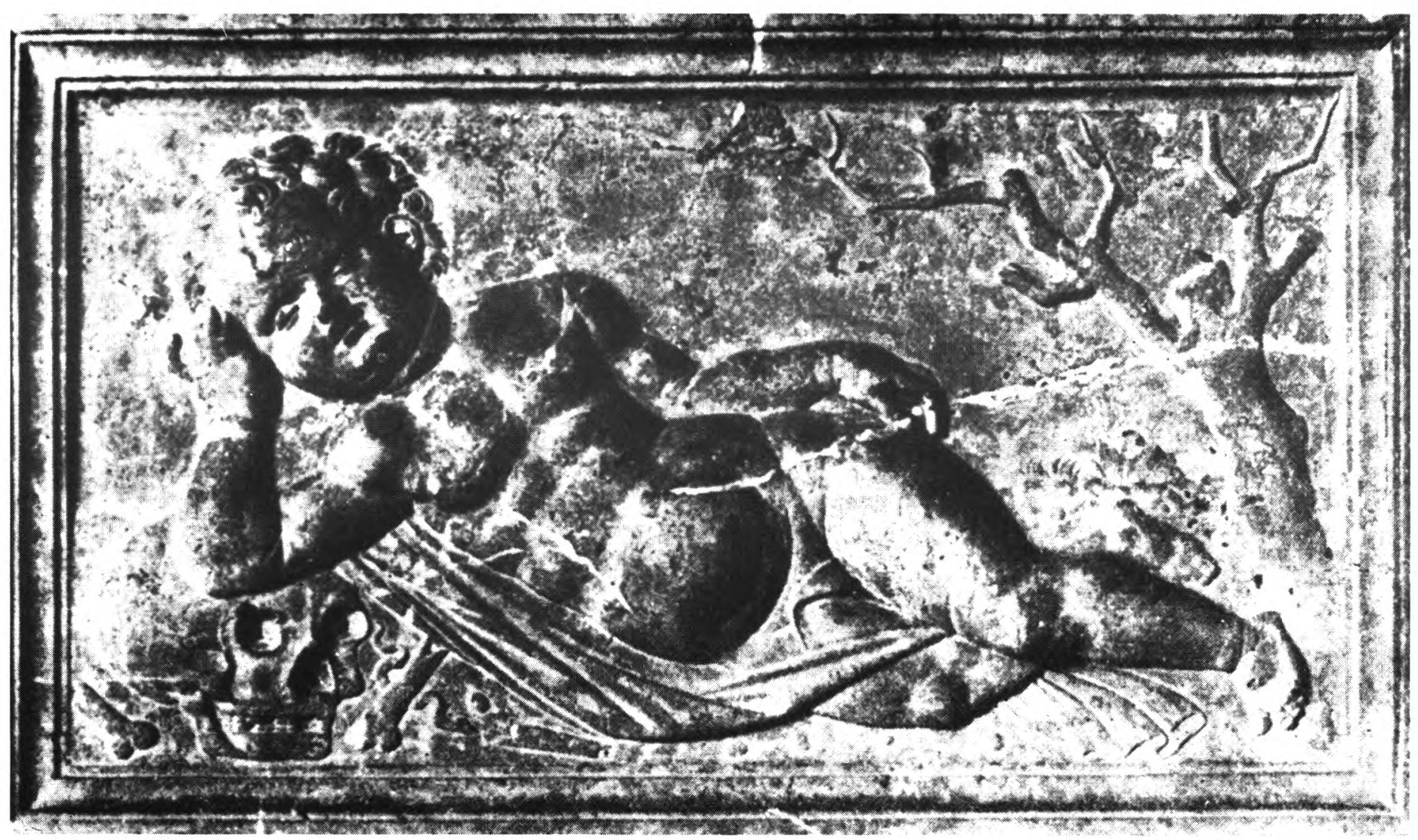

12. Nagrobek Rafała Ocieskiego, po 1547, Kościół OO. Dominikanów, Kraków. 


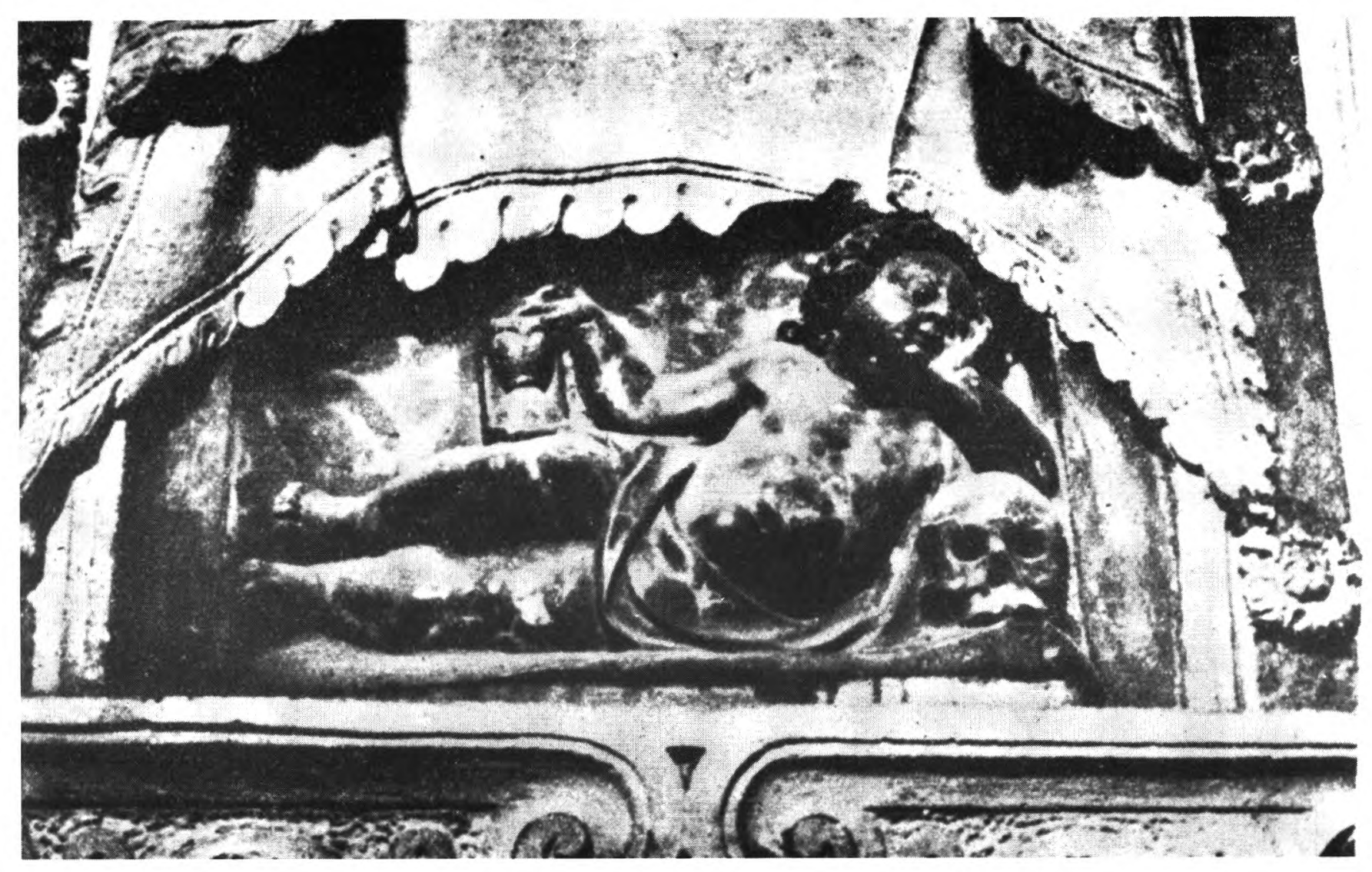

13. Dziecko z czaszką i klepsydrą, rzeźba w kaplicy Firlejów w Bejscach, XVI/XVII w. 


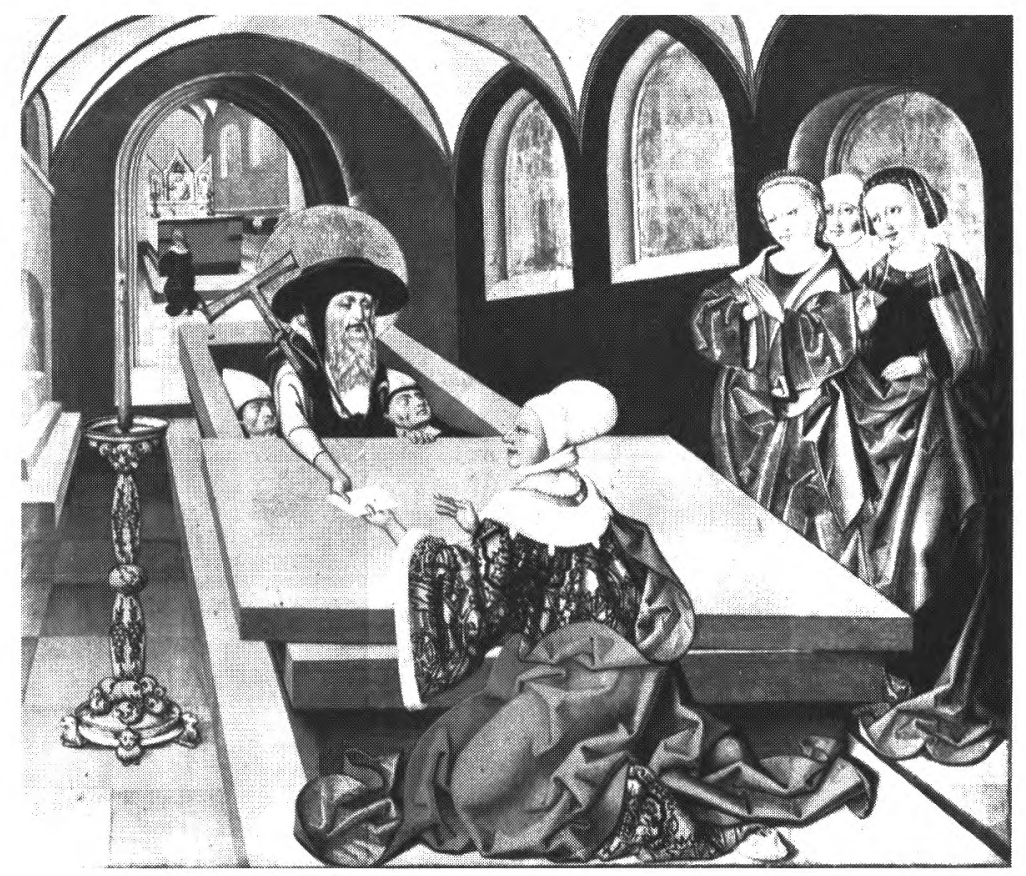

14. Cud u grobu patriarchy, część ołtarza św. Jana Jałmużnika, 1504, Kraków, Muzeum Narodowe, Kamienica Szołajskich.

15. Wytudzenie pieniędzy przez Nicetę, część ołtarza św. Jana Jałmużnika 1504, Kraków, Muzeum Narodowe, Kamienica Szolajskich.

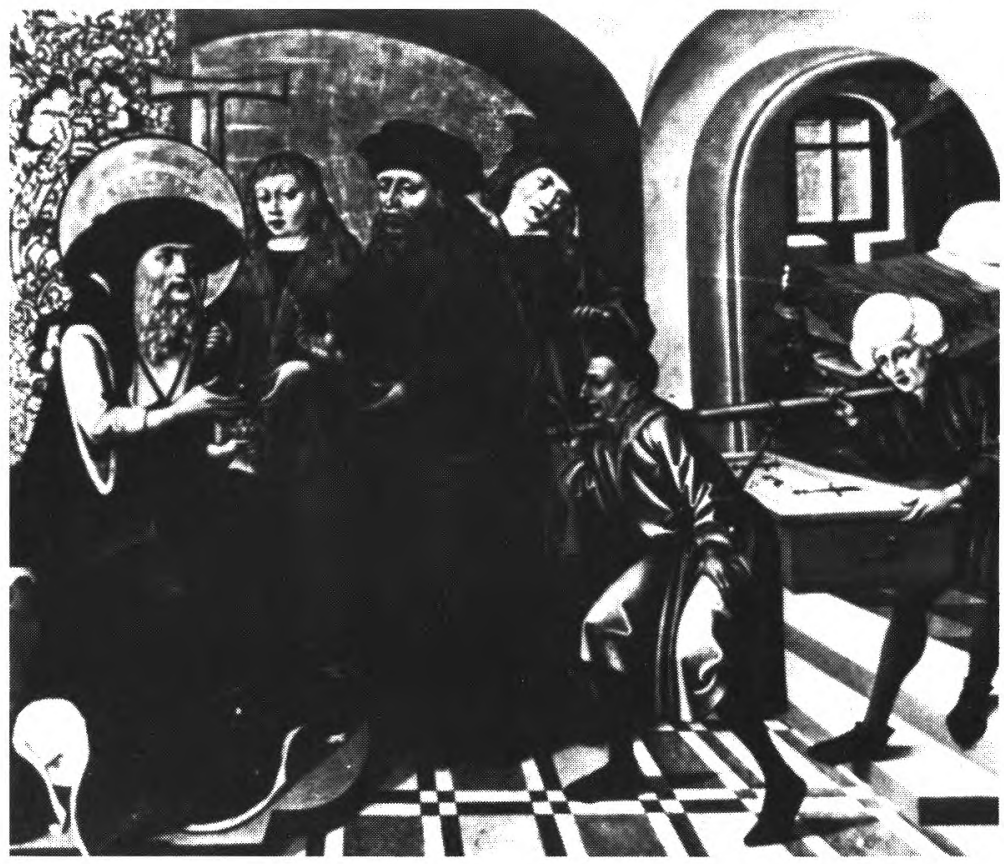




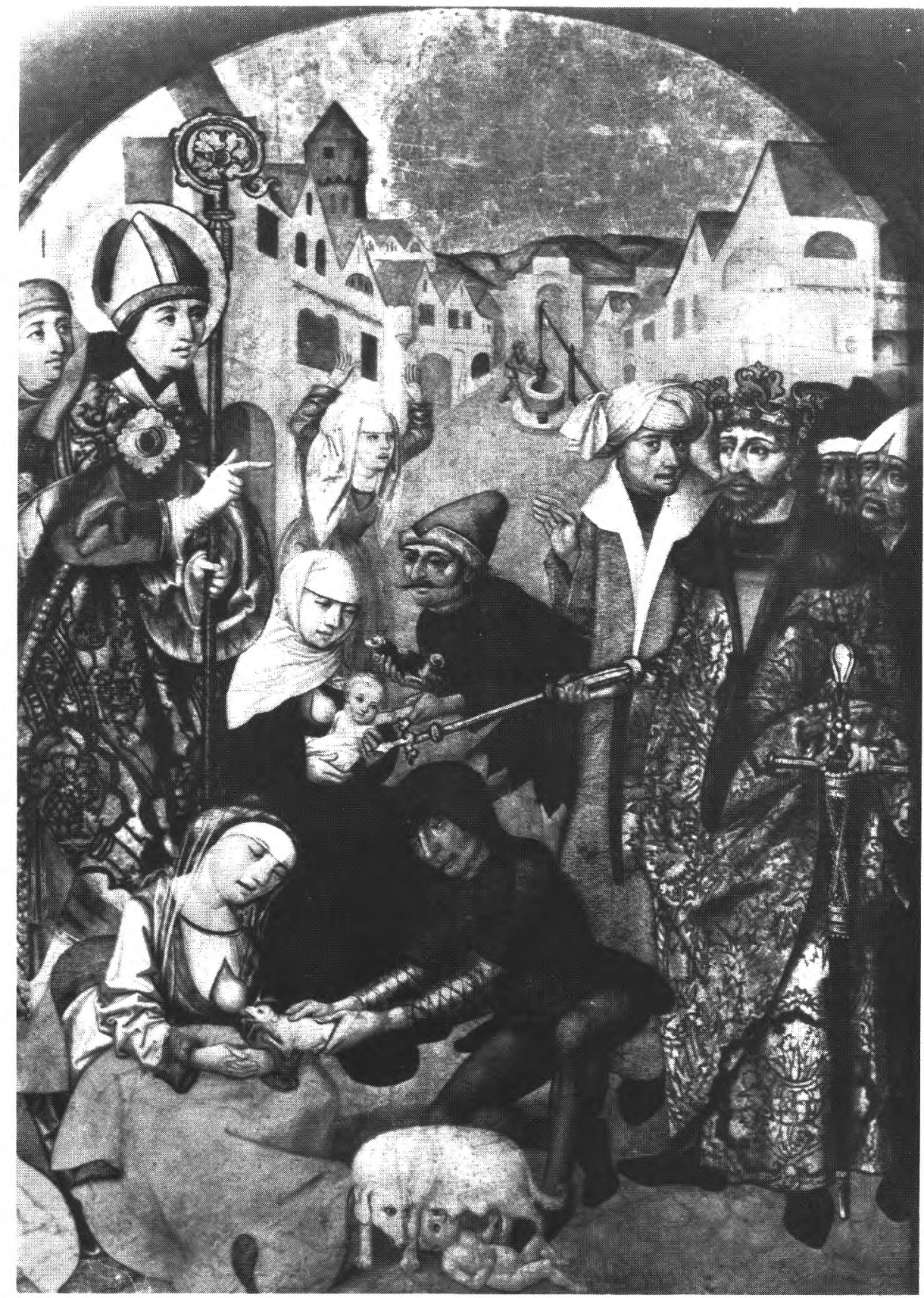

16. Ukaranie niewiernych żon, kwatera ołtarza ze Skałki, ok. 1504, zamek w Pieskowej Skale. 


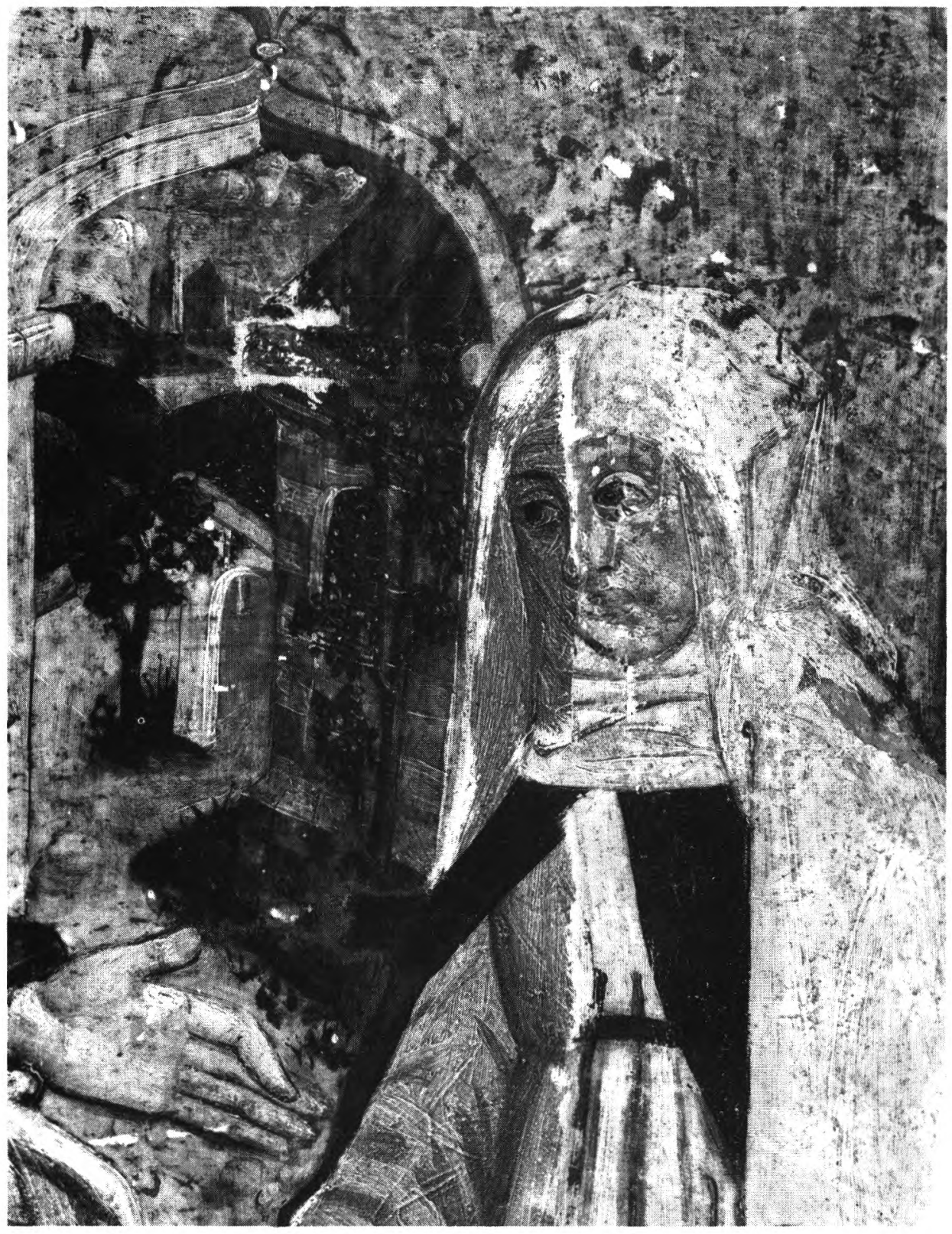

17. Pejzaż, fragment sceny: Św. Katarzyna obdarowana ptaszczem przez Chrystusa (zob. il. 8). 
tylko niedostatkiem przyrodzenia, ale też sprawą nieprzyjaciela [złego ducha], iż wszystkie z niej wnętrzności obyczajem przyrodzonym, wzruszone były, zkąd wielkie ochydzenie żołądek jej cierpiał. Panna chwalebna tem ciężej ono na umyśle znosiła, im dni onych przez nowe zwycięstwo za łaską Ducha św. nowych cnót doskonałości dosięgała. Zkąd przeciwko ciału własnemu przez świętą nienawiść powstawszy rzecze: Żywie najwyższy, Oblubieniec najmilszy duszy mojej; albowiem to, czem się ty tak dalece brzydzisz w jelitach twoich się zawrze. Natychmiast tedy onej rany sprośnej umycie z ropą w miskę zebrawszy i odszedłszy na stronę wszystko wypiła".

W nagrodę ukazał się Katarzynie Chrystus i pozwolił pić krew ze swego boku: ,[...] nocy przyszłej ukazał się jej na modlitwie będącej Pan i Zbawiciel Jezus Chrystus, okazując na ciele swoim pięć onych ran najświętszych, które niegdyś podjął dla zbawienia naszego na drzewie krzyża świętego. I rzecze: Wiele, najmilsza moja dla mnieś stosów wytrzymała, i za pomocą moją wszystkoś dotąd zwyciężyła, dlaczego stałaś mi się wielce wdzięczną i przyjemną [...] Dlaczego powiadam ci, iż w tym uczynku przeszłaś przyrodzenie twoje, tak ja dam tobie napój, który wszystko ludzkie przyrodzenie i zwyczaj przechodzi. I włożywszy prawą rękę swoją na plecy panieńskie, one ku przebiciu boku Swego przywiódłszy, rzecze: Pijże córko moja z boku mego napój, którym dusza twoja słodkością tak wielką będzie napełniona, że też i na ciało, któreś dla mnie wzgardziła dziwnie się wyleje" 46 .

Scena dolna awersu lewego skrzydła przedstawia po prawej od widza wnętrze kościoła z ołtarzem malowanym. Na mensie otwarty mszal i kielich. U stopni ołtarza klęczy zakonnik. Po lewej od widza stronie sceny postać Chrystusa, który udziela komunii św. Katarzynie (il. 2). Scena ta znajduje taki opis w legendzie: „Albowiem, gdy towarzyszki moje nie chciały, abym poranku tego przystępowała, dla szemrania niektórych, nie chcąc ich zasmucić, dla zgorszenia drugich, uciekłam się do Oblubieńca mego najłaskawszego, a On obecnie ukazawszy się mi cząstką ową, od was wziętą, mnie miłościwie podać raczył. A jam ją z rąk Jego najświętszych przyjęła" 47 .

Scena na prawym awersie u góry przedstawia również dwa epizody zawarte w jednym obrazie. Jest to Wymiana serc między Katarzyna a Chrystusem (il. 3). Zaczyna się opisem: „Zdało się jej, iż Wieczny Oblubieniec do niej obyczajem zwykłym przyszedł i bok jej lewy otworzył, serce stamtąd wyjąwszy odszedł. Tak tedy ona bez serca na zawsze została"48. Dalszy ciąg wydarzenia opisuje legenda: „Dnia tego jednego, gdy była w kaplicy kościoła Dominika św. [...] wstała, aby szła do domu. Natychmiast światłość ją z nieba otoczyła i w onej światłości ukazał się jej Pan, mając w najświętszych rękach swoich serce jakieś człowiecze rumiane i jasne. Gdy tego na przyjście wszego świata spra-

46 Tamże, s. $145-147$.

47 Tamże, s. 297.

48 Tamże, s. 167. 
wce i światłości onej skłoniwszy się upadła na ziemię, Pan się ku niej przybliżywszy, bok jej lewy otworzył i serce ono, które w ręce miał, tam włożywszy, rzecze: „Oto, córko najmilsza, jakom ci ongi wziął serce twoje, tak też teraz daję ci serce moje, abyś z niem zawsze żyła. A to wyrzekłszy onę aperturę, którą w jej ciele był uczynił, zamknął i utwierdził. I na znak cudu na tem miejscu bliżna znakomita została" 49 .

Scena na awersie w dole prawego skrzydła przedstawia św. Katarzynę napastowaną przez demony (il. 4). Udręczenie przez demony powtarza się wielokrotnie w legendzie, tu jednak legenda znajduje dosłowną ilustrację: „Lecz gdy już król nieba i ziemi, wieżę swoją filary dużymi nauki swej, mocno opatrzył, nieprzyjaciołom ku niej szańcować dopuścił, aby przystąpili i spróbowali, jeśliby ją sposobem jakim poruszyć mogli. Oni ku niej przez obrzydliwe wojsko swoje szturmując, najprzód starali się aby ją wkoło otoczyli, żeby tak pomocy nie mając mogli ją z fundamentem wywrócić" 50 .

Jak widać z powyższego opisu źródłem przedstawień ołtarza była Legenda major Rajmunda z Kapui, którą malarz, czy raczej malarze, gdyż było ich kilku, musieli dokładnie znać. Wynika z tego, że egzemplarz Legendy musiał się znajdować w Krakowie. Dotychczasowe moje poszukiwania archiwalne tego egzemplarza, zarówno wśród rękopisów, jak i inkunabułów, nie dały rezultatu. Główną tego przyczyną są zniszczenia biblioteki klasztornej w czasie kilku pożarów. L. Lepszy tak pisze na ten temat: „Obecny księgozbiór nie może się równać pod względem starożytności ani z karmelickim, ani też z bernardyńskim, zawsze jednak najstarsze z ksiąg sięgają połowy XV w. Stan pierwotny musiał być inny [...]. Już fragmenty okuć, które się dochowały, mówią o tem najwymowniej. I możemy nie uchybiając prawdzie, przyjąć za rzecz pewną, że księgozbiór dominikański był największy spośród bibliotek klasztornych krakowskich i tylko wskutek pożarów w latach 1462, 1688 i 1850 przedstawia się dzisiaj jako wspaniała tylko reszta dawnego bogactwa"51.

\section{Warsztat i forma}

Ktokolwiek, choćby pobieżnie zna polskie malarstwo tablicowe, nasunie mu się analogia drugiej ilustracji Legendy Rajmunda (dolna kwatera rewersu lewego) ze sceną w krakowskim ołtarzu Jana Jałmużnika, przedstawiająca Cud u grobu patriarchy (il. 14); i tu i tam pokazano na pierwszym planie właściwą scenę, a w dali, w osobnym wnętrzu, mały rzeźbiony tryptyk. Nie jest to zbieżność przypadkowa. Scena Leczenia chorych przez Katarzynę (il. 7) ma podobne rozwiązanie perspektywiczne jak w ołtarzu Jałmużnika w scenie: $W y$ -

49 Tamże, s. 168

50 Tamże, s. 76.

${ }^{51}$ L. Le ps zy, Miniaturzyści dominikańscy, „Rocznik Krakowski” 20 : 1926 s. 117 n. 
tudzenie pieniędzy przez Nicetę (il. 15). Po prawej stronie sceny ukazano drugie wnętrze otwierające się szerokim portalem. W tej wnęce widać łóżko, w wypadku Jałmużnika zasłane, w wypadku legendy Katarzyny — z leżącymi chorymi. W całym cyklu, nowo odkrytym na rewersach, istnieje tendencja do pokazywania portali lub okna ukazujących drugie wnętrze lub pejzaż.

Polityk św. Jana Jałmużnika, ufundowany dla krakowskiego klasztoru Augustianów przez Mikołaja Lanckorońskiego, którego herb Zadora widnieje w dolnej części środkowej tablicy poliptyku, powstał około roku 1504, w czasie gdy docierają już do Polski prądy renesansu. Znajomość nowego kierunku ujawnia się w stosowaniu praw perspektywy, rozbudowanych wnętrzach mieszkalnych i w ujęciach pejzażowych, wreszcie w tendencji do portretowych indywidualizacji twarzy przedstawianych ludzi. Poliptyk zachowal się we fragmentach i trudno ustalić jego początkowy wygląd. Autor poliptyku, ciekawa indywidualność na tle ówczesnego malarstwa krakowskiego pozostaje postacią nieznaną. Próbowano wyprowadzić genezę jego sztuki ze środowiska węgierskiego $^{52}$. M. Walicki uznał tego mistrza za malarza działającego w Krakowie, ale obznajomionego ze sztuką Szwabii i Styrii, zwłaszcza z działalnością Jorga Breua i styryjskiego Mistrza legendy Daniela ${ }^{53}$. Monografistka ołtarza K. Secomska potwierdza tezę Walickiego o związkach ze sztuką Jorga Breua, ale również, jako dość silnie związaną z ołtarzem Jałmużnika, uznaje grupę ołtarzy $\mathrm{z}$ terenu Spisza ${ }^{54}$. Jednakże zarówno Walicki, jak i Secomska, jako argument za działalnością Mistrza ołtarza św. Jana Jałmużnika w Krakowie przytaczają zbieżny stylowo z ołtarzem Jałmużnika zespół ołtarzowy z przedstawieniami legendy św. Stanisława (il. 16) z kościoła Paulinów na Skałce w Krakowie ${ }^{55}$. Dla naszych badań teza ta ma duże znaczenie, ponieważ w jednej ze scen ołtarza ze Skałki istnieją elementy zbliżone do fragmentów naszego ołtarza; w tle sceny Ukaranie niewiernych $\dot{z} o n^{56}$ widzimy ulicę $\mathrm{z}$ widokiem domów, w głębi zaś maleńkie przedstawienie studni z człowiekiem czerpiącym z niej wodę. W naszym ołtarzu w tle sceny $S w$. Katarzyna leczy chorych (il. 7) znajduje się również prawie niewidoczna uliczka z przedstawieniem fontanny. Zachowano tu prawa logiki: w Polsce, gdzie dzieje się scena z legendy św. Stanisława, pokazano studnię, we Włoszech — fontannę.

Te elementy zapożyczone od Mistrza ołtarza św. Jana Jałmużnika, przy zupełnie innej budowie formy, świadczą, że malarz naszych malowideł zapoznał się jedynie $\mathrm{z}$ ołtarzem Jałmużnika lub był zaledwie uczniem mistrza. Większość postaci naszego ołtarza namalowano topornie; fałdy układają się sztyw-

52 I. Ge n th on, A regi magyar festömüvéset, Vac 1932, s. 61. 323.

${ }^{53}$ M. W a li c ki, Malarstwo polskie. Gotyk, renesans, wczesny manieryzm, Warszawa 1961, s.

${ }^{54}$ K. S e co m s k a, Ottarz św. Jana Jatmużnika, „Studia Renesansowe” 4: s. 244 n., 309-312.

${ }_{55} \mathrm{M}$. Walicki, jw., s. $322 \mathrm{n}$.

${ }_{56} \mathrm{M}$. Ot t o-Michal ow s k a, Gotyckie malarstwo tablicowe w Polsce, Warszawa-Berlin-Budapeszt 1982, $\mathrm{nr} 26$. 
no, rysy twarzy przy nieumiejętności operowania światłocieniem odtworzone są kreską. Wszystko to najlepiej widać w scenie Katarzyna ze św. Dominikiem (il. 6). Przy takich błędach malarskich zadziwia umiejętność odtworzenia szczegółów. Np. ołtarz, przedstawiony w głębi sceny, aczkolwiek małych wymiarów, jest tak odtworzony, iż widać, że jest to tryptyk rzeźbiony, a nie malowany. Mały portal koło ołtarza pozwala dostrzec w głębi maleńki domek. Ta sama ręka wykonała jeszcze dwie kwatery rewersów: $S w$. Katarzyna leczy chorych (il. 7) i Sw. Katarzyna obdarowana jest przez Chrystusa ptaszczem (il. 8). We wszystkich trzech scenach widać te same cechy: słaba umiejętność odtwarzania elementów dużych i zamiłowanie do szczegółów. W dwu z tych kwater, jak już wspomniałam, architektura wnętrza wykazuje zapożyczenie $\mathrm{z}$ ołtarza św. Jana Jałmużnika. Trzecia scena „obdarowanie płaszczem” zawiera z kolei nowatorsko przedstawiony pejzaż, widoczny przez namalowany w głębi portal (il. 17). Wszystkie te cechy wskazują, że twórca tych trzech kwater był malarzem młodym, otwartym na nowe zdobycze wiedzy malarskiej, ale jeszcze niedouczonym.

Zupełnie inaczej przedstawia się sprawa z malarzem dwu kwater awersów po lewej i prawej stronie. Są one malowane z pewnością przez jednego malarza. Figura Chrystusa jest prawie tak samo ukształtowana, głowy w cierniowej koronie podobne (il. 1,3). Jednak ten typ postaci i twarzy Chrystusa wskazuje na mistrza starszego, wyszkolonego jeszcze w ostatniej ćwierci XV w. Malowidła przez niego malowane przypominają wiele dzieł z tego okresu, zwłaszcza częstą w malarstwie małopolskim scenę Maria Bolesna i Vir Dolorum ${ }^{57}$. Jedną z takich analogii dostrzegł T. Sadziak, przypominając tryptyk z Żernik. Najwybitniejszym malarzem naszego cyklu i być może kierownikiem warsztatu był mistrz, który zarówno w kształtowaniu wnętrza, jak i przedstawianiu postaci ludzkiej, wykazywał duże umiejętności. Mistrz ten wykonał kwaterę dolną lewego awersu, kwaterę dolną prawego awersu i kwaterę górną lewego rewersu. Kwatera awersu przedstawiająca Komunię św. Katarzyny (il. 2) ma wprawdzie tradycyjne złote tło po lewej od widza, ale druga część tła to, z dużą umiejętnością przedstawione, wnętrze kościelne z ołtarzem o malowanej nastawie z leżącym na mensie mszałem i stojącym kielichem. Na stopniach ołtarza klęczy zakonnik, którego proporcje są wyważone w stosunku do postaci na pierwszym planie. Postacie te malowane są z dużą umiejętnością. Modelunek ich twarzy, zwłaszcza twarzy Chrystusa, jest subtelny, z dostrzegalnym światłocieniem, delikatnymi pasmami włosów na głowie i zaroście. Ręce przedstawione w miękkim ruchu. Także i ręce klęczącego zakonnika przedstawione są w umiejętnie wydobytym geście.

Dolna kwatera awersu prawego, przedstawiająca $S w$. Katarzynę napastowanq przez demony (il. 4), wykonana jest również doskonale. E. Fejkel uwa-

${ }^{57}$ T. Sadziak, jw., s. 18. 
żała, że pierwowzorem malowidła był miedzioryt Martina Schongauera z ok. 1470 r., przedstawiający kuszenie św. Antoniego ${ }^{58}$. Wobec tego, iż obraz nasz ilustruje dokładnie tekst Legendy Rajmunda, podobieństwo to może być przypadkowe. Obraz jest dziełem malarza wysokiego lotu. Postać Świętej przedstawiona w umiejętnie oddanym kontrapoście. Twarz modelowana światłocieniem. Księga wisząca w torebce na pasku poprawnie się układa. Postacie demonów zadziwiają modelunkiem prawie rzeźbiarskim i doskonale oddanymi dziwnymi pozami.

Trzecie dzieło, które wydaje się wykonane przez trzeciego mistrza, jest niezwykle ważne treściowo i formalnie, otwiera ono bowiem opowiadanie legendy i zawiera wiele elementów z niej zaczerpniętych oraz symboliczne przedstawienie klepsydry. Jest to kwatera górna rewersu lewego skrzydła, przedstawiająca Umartwienia Świętej (il. 5). Pomimo iż nie została ona jeszcze w całości odsłonięta, demonstruje cechy, na podstawie których można ją związać $\mathrm{z}$ najbardziej zdolnym $\mathrm{z}$ trzech malarzy. Jest tu głębokie wnętrze z poprawnie namalowaną skrzynią. Wizerunek Świętej, klęczącej i biczującej się łańcuchem, jest przedstawiony ze znajomością anatomii. Wreszcie znajomość nowej symboliki vanitas wskazuje, że malarz był twórcą wykształconym, o dużej kulturze.

Malarz ten czuwał nad rozwiązaniem kompozycyjnym całości. Swiadczy o tym również kolorystyka ołtarza. Dwa awersy górne (il. 1,3), które po otwarciu ołtarza stanowiły odpowiadającą sobie całość, są rozwiązane podobnie. I tu, i tam główny akcent kolorystyczny stanowi płaszcz okrywający nagie ciało Chrystusa. Jest on namalowany w kolorze cynobru i ma podszycie zielone. W lewym awersie takie rozwiązanie narzucała treść, gdyż obnażone ciało umożliwiało pokazanie ran i rany w boku, z której Święta pije krew. W prawym awersie nie było to konieczne, a ukazano tam obnażone ciało okryte płaszczem czerwono-zielonym dla równowagi kompozycyjnej. Obok tego czarno-biała szata Swiętej i architektura w kolorze szarym. W kwaterze dolnej awersu prawego Chrystus ma szaty w kolorze ciemnego szafiru (il. 2). Mnich ubrany w ornat dobrze imitujący wzorzystą, złotą tkaninę, pod tym szata biała. Ołtarz ma mensę czerwoną i obrus biały z czerwonym wzorem. Nastawa ołtarza (tryptyk) przedstawia Madonnę z Dzieciątkiem, a na skrzydłach postacie świętych dziewic. Obramienie rzeźbiarskie ołtarza dobrze imituje kolor złoty. Architektura w kolorze szarym o różnym nasileniu. W kwaterze dolnej awersu prawego dominuje postać Świętej w szacie czarno-białej. Demony w różnych odcieniach brązu.

Kwatera górna na lewym rewersie przedstawia Świętą w szacie białej (il. 5). Architektura wnętrza: róż i jasny brąz. Ława z klepsydrą o blacie jasno brązowym z widocznymi słojami drewna; dolna część ławy różowa. Posadzka cza-

${ }^{58}$ E. Fejkiel, jw., s. 116. 
rno-zielona. Klepsydra żółta — imitacja złota. W kwaterze górnej prawego rewersu dominuje czarno-biała postać Świętej. Portal szary, podłoże kamienne, na którym stoi Swięta w tonach jasnobrązowych. Obramienie wnęki złotawy brąz, posadzka czarno-brązowa.

W kwaterze dolnej rewersu lewego postać Świętej odziana w suknię zieloną i płaszcz ciemnoróżowy, włosy dobrze imitują kolor złoty (il. 6). Święty Dominik - szaty czarno-białe. Na lewym ręku trzyma płaszcz szaro-brązowy, na prawym - biały. Architektura wnętrza w różnych odcieniach szarości. Witraże bladożółte. Ołtarzyk w głębi, dobrze imitujący rzeźbę złoconą; można odczytać przedstawienia na nim zamieszczone: pośrodku Ukrzyżowanie, po obu stronach postacie świętych kobiet, predella Misericordia omni. Posadzka od przodu bladoróżowa, w głębi jasnoszara. Kwatera dolna rewersu prawego przedstawia Chrystusa w niebieskiej szacie (il. 8). Architektura wnętrza w kolorach złotawo-różowym, ściana z oknem witrażowym ciemny róż. Pejzaż widoczny przez okno w tonach złotawo-brązowych. Kościółek biały z czerwonym dachem (il. 17).

Warsztat malarski naszego ołtarza wykazuje wiele cech nowatorskich, także w kolorystyce; wiele tu kolorów delikatnych. Dominują złociste brązy i różne odcienie barwy różowej oraz różne rodzaje szarości. Mistrz warsztatu, jak i współpracownicy pozostają postaciami anonimowymi. Datowanie ołtarza w związku z analogiami do ołtarza Jana Jałmużnika można ustalić na pierwsze 10-lecie XVI wieku (terminus post quem jest rok 1504). W sumie ten zespół ołtarzowy stanowi ciekawy przykład w malarstwie polskim XVI wieku.

I tak to kościół oo. Dominikanów w Krakowie jeszcze raz okazuje się skarbnicą wybitnych dzieł sztuki. Dla niego wykonano Ottarz dominikański z lat ok. $1460-1470^{59}$. Tu zachowala się Ptyta Kallimacha - poety, filozofa i humanisty, odlana z brązu po 1496 r. w pracowni P. Vischera St. w Norymberdze według projektu Wita Stwosza ${ }^{60}$. Tu powstał w początkach XVI wieku cenny rękopis Rozmyślań dominikańskich ${ }^{61}$. Tu znajdują się obrazy T. Dolabelli z lat $1619-1625^{62}$. Nasz ołtarz stanowi jeszcze jedno ciekawe, związane z tym kościołem, dzieło sztuki63. 1963.

59 J. G adomski, jw., s. $124-130$.

${ }^{60}$ A. B o chna k, Pomnik Kallimacha, „Studia Renesansowe” 1: 1956 s. $124-139$.

61 Rozmyślania dominikańskie, wyd. i opr. K. Górski i W. Kuraszkiewicz, Wrocław

62 T. To m kiewicz, Dolabella, Warszawa 1959, passim.

${ }^{6}$ Wszystkim, którzy udzielili mi pomocy i rady uprzejmie na tym miejscu dziekuję: Panu Docentowi Tadeuszowi Dobrzenieckiemu za udostępnienie mi obustronnie malowanej kwatery omawianego ołtarza, znajdującej się po konserwacji w Muzeum Narodowym; Pani Profesor Alicji Karlowskiej-Kamzowej za przekazanie mi ważnych informacji; Ojcu Zbigniewowi z klasztoru oo. Dominikanów w Warszawie za udostępnienie mi księgozbioru klasztornego; Bratu Pawłowi Krupie z klasztoru oo. Dominikanów w Krakowie za życzliwe dokonanie kwerendy w bibliotece klasztornej; Pani Magister Annie Kapuścińskiej-Rafałko za pomoc w uzyskaniu trudno dostępnych książek. Szczególną wdzięczność winna jestem Profesorowi Janowi Samkowi. 


\section{DER ALTAR MIT DER HLG. KATHARINA VON SIENA AUS DER DOMINIKANERKIRCHE IN KRAKAU}

\section{Zusammenfassung}

Im Lagerraum des Nationalmuseums in Warschau wird seit 1947 das geteilte Triptychon mit der Hlg. Katharina von Siena aus der Dominikaner-Kirche in Krakau aufbewahrt. Über diesen Altar sind bisher keine wissenschaftlichen Veröffentlichungen erschienen, er war nur das Thema dreier Diplomarbeiten von Studenten der Kunstakademie zu Warschau. Wegen der fehlenden Popularisierung dieses Kunstwerkes haben es die Wissenschaftler für verschollen erklärt.

Der Altar stellt auf den Aversen folgende Szenen dar: Die Hlg. Katharina, Blut aus dem Körper Christus trinkend; Christus erteilt der Hlg. Katharina Kommunion; Herzenaustausch zwischen der Hlg. Katharina und Christus; Die Hlg. Katharina von den Dämonen geplagt. Auf den Reversen sind dargestellt: Das Martern der Hlg. Katharina; Die Hlg. Katharina mit dem Hlg. Dominik; Die Hlg. Katharina heilt Kranke; Die Hlg. Katharina, beschenkt durch Christus mit dem Mantel. Der Szenenzyklus wurde anhand des Katharina-Heiligenlebens gemalt, das von ihrem Beichtvater, Raimund von Kapua, niedergeschriben wurde.

Der Altar ist ein seltenes Kunstwerk in Polen, das der Hlg. Katharina von Siena gewidmet ist. Neben diesem Objekt gibt es nur noch eine frühere Darstellung der Heiligen auf den Altarflügel aus Kujawy, z. Zt. im Bezirksmuseum in Thorn. Der Krakauer Altar schmückte ursprünglich die Kapelle der Hlg. Katharina von Siena (später Zbaraski-Kapelle) in der Dominikaner-Kirche in Krakau. Er wurde im ersten Jahrzehnt des 16. Jahrhunderts von drei Malern ausgeführt, deren Werkstatt Zusammenhänge mit dem Stil eines in Krakau wirkenden Meisters aufweisen, der den Hlg. Johannes-der Almosengeber-Altar geschaffen hatte. Besonders beachtenswert ist die Szene Das Martern der Hlg. Katharina, die wegen der dargestellten Sanduhr und der Vanitas-Aufschrift auf dem Spruchband an den Vanitas-Typ anknüpft. Das ist die erste der Darstellungen in Polen und überhaupt eine der frühesten. 